\title{
Lead, Mercury and Cadmium in Fish and Shellfish from the Indian Ocean and Red Sea (African Countries): Public Health Challenges
}

\author{
Isidro José Tamele ${ }^{1,2,3, *(\mathbb{D})}$ and Patricia Vázquez Loureiro ${ }^{4}$ \\ 1 Department of Chemistry, Faculty of Sciences, Eduardo Mondlane University, Av. Julius Nyerere, n 3453, \\ Campus Principal, Maputo 257, Mozambique \\ 2 Institute of Biomedical Science Abel Salazar, University of Porto, R. Jorge de Viterbo Ferreira 228, \\ 4050-313 Porto, Portugal \\ 3 CIIMAR/CIMAR - Interdisciplinary Center of Marine and Environmental Research, University of Porto, \\ Terminal de Cruzeiros do Porto, Avenida General Norton de Matos, 4450-238 Matosinhos, Portugal \\ 4 Department of Analytical Chemistry, Nutrition and Food Science, Faculty of Pharmacy, University of \\ Santiago de Compostela, Santiago de Compostela, 15782 A Coruña, Spain; patriciavazquez.loureiro@usc.es \\ * Correspondence: isitamele@gmail.com
}

Received: 20 March 2020; Accepted: 8 May 2020; Published: 12 May 2020

\begin{abstract}
The main aim of this review was to assess the incidence of $\mathrm{Pb}, \mathrm{Hg}$ and $\mathrm{Cd}$ in seafood from African countries on the Indian and the Red Sea coasts and the level of their monitoring and control, where the direct consumption of seafood without quality control are frequently due to the poverty in many African countries. Some seafood from African Indian and the Red Sea coasts such as mollusks and fishes have presented $\mathrm{Cd}, \mathrm{Pb}$ and $\mathrm{Hg}$ concentrations higher than permitted limit by FAOUN/EU regulations, indicating a possible threat to public health. Thus, the operationalization of the heavy metals $(\mathrm{HM})$ monitoring and control is strongly recommended since these countries have laboratories with minimal conditions for HM analysis.
\end{abstract}

Keywords: heavy metals; seafood monitoring; Indian Ocean; Red Sea; lead; mercury; cadmium; public health

\section{Introduction}

Seafood (fish and shellfish) is one of the main food and international economic sources in many coastal countries [1,2]. Additionally, it contains an essential nutritional composition which is crucial to human diet such as vitamins D, B12, A and E (for bones fortification [3]; nucleic acids synthesis, red blood cell and neurological function [4]; maintenance of vision and respiratory tract [5]; and for antioxidant defense [5], respectively), minerals [Selenium (for antioxidant defense and thyroid function regulation) [6], calcium (for maintenance of bones and teeth) [7], Zinc (for enzymatic catalysis for human metabolism and immune system functioning) [5], Iron (for oxygen transportation in the blood) [8], proteins (for enzymatic composition) [9], lipids [ $\omega-3$ polyunsaturated fatty acids, especially eicosapentaenoic acid and docosahexaenoic acid (for prevention the of heart disease due to low cholesterol content) [10]], iodine (for the production and functioning of the thyroid) [8] and others.

On the other hand, seafood is one of the vectors of heavy metals (HM) occurring naturally or introduced in the marine environment by different human activities, mainly, port activities, mineral resources extraction in marine and fluvial environments or untreated discharges of chemical industries or domestic wastes [11-25]. Reported HM that are environmentally relevant due to their effects on the species found in the marine environment, including seafood, which constitute a threat for public 
health, include: lead $(\mathrm{Pb})$, mercury $(\mathrm{Hg})$ and cadmium $(\mathrm{Cd})$ [11-25], due to their involvement in the activation of enzymes and biochemicals, constituting a base for human organism functioning.

The presence of HM in seafood is one of the main threats to public health, and its monitoring and control has to be done rigorously in African countries of the Indian Ocean and the Red Sea, where most of the seafood from marine environments are consumed directly without quality control due to poverty $[20,26,27]$. Thus, the main objective of this review was to assess the incidence of $\mathrm{Pb}, \mathrm{Hg}$ and $\mathrm{Cd}$ in seafood from African Indian and the Red Sea coasts and the level of their monitoring and control;

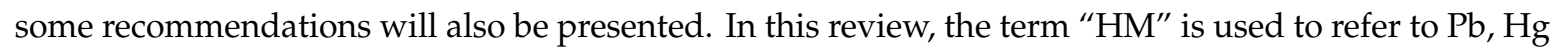
and $\mathrm{Cd}$ and "seafood" to refer to fish and shellfish.

\section{Heavy Metals and Their Effects on Humans}

The occurrence of HM in seafood is one of the main threats to public health since they cause several negative effects in humans, of which the most reported induce oxidative stress [28-36] and inactivation of crucial molecules in the human organism, such as sulfhydryl groups [metallothionein (MT) $[37,38]$ and glutathione (GSH)] [39,40] for Cd, $\mathrm{Hg}$ and delta-aminolevulinic acid dehydratase, delta-aminolevulinic acid synthase and ferrochelatase for $\mathrm{Pb}$ [41]. Thus, the control and monitoring of HM in seafood is most important to minimize associated seafood poisoning. The monitoring of $\mathrm{HM}$ in seafood requires active organization because there are a lot of aspects that have to be taken into consideration, from the sampling process to data interpretation. HM occurs in seafood in the form of different species distributed in a heterogeneous manner in different seafood tissues. Different monitoring programs of $\mathrm{HM}$ (Table 1) specify the edibles tissues (generally muscle) and seafood species to be monitored and recommend the permitted HM limit for each tissue and species (Table 1). The analytical methods that are used for HM monitoring, the different human biomarkers and the methods of their detection are described in Table 1. The most reliable HM biomarker is their presence in essential biological fluids, such as urine and blood, since the biochemical biomarkers seem similar for many HMs [20,26,27,42-44]. HM poisoning treatments consist generally of the administration of chelating agents that complex the HM and that are later excreted in urine.

Table 1. Lead compounds toxicologically relevant. TtEL—tetraethyllead, TEL—trimethyl lead, TML—trimethyl lead, $\mathrm{X}$-halide $(\mathrm{Cl})$.

\begin{tabular}{cccccc}
\hline \multicolumn{1}{c}{ Structure } & $\mathbf{R}_{\mathbf{1}}$ & $\mathbf{R}_{\mathbf{2}}$ & $\mathbf{R}_{\mathbf{3}}$ & $\mathbf{R}_{\mathbf{4}}$ & Name \\
\hline $\mathrm{R}_{1}$ & $\mathrm{CH}_{3} \mathrm{CH}_{2}$ & $\mathrm{CH}_{3} \mathrm{CH}_{2}$ & $\mathrm{CH}_{3} \mathrm{CH}_{2}$ & $\mathrm{CH}_{3} \mathrm{CH}_{2}$ & TtEL \\
$\mathrm{R}_{4}-\mathrm{Pb}-\mathrm{R}_{2}$ & $\mathrm{X}$ & $\mathrm{CH}_{3} \mathrm{CH}_{2}$ & $\mathrm{CH}_{3} \mathrm{CH}_{2}$ & $\mathrm{CH}_{3} \mathrm{CH}_{2}$ & TEL \\
\hline $\mathrm{R}_{3}$ & $\mathrm{X}$ & $\mathrm{CH}_{3}$ & $\mathrm{CH}_{3}$ & $\mathrm{CH}_{3}$ & TML \\
\hline $\mathrm{PbSO}_{4}$ & - & - & - & - & Lead sulphate \\
\hline $\mathrm{Pb}_{3}\left(\mathrm{PO}_{4}\right)_{2}$ & - & - & - & - & Lead phosphate \\
\hline $\mathrm{PbS}$ & - & - & - & - & Lead sulfide \\
\hline $\mathrm{PbCO}_{3}$ & - & - & - & & Lead carbonate \\
\hline
\end{tabular}

\subsection{Cadmium}

Cadmium usually occurs in the environment in the ionic form $\mathrm{Cd}^{2+}\left(\mathrm{Cadmium}\right.$ oxide $-\mathrm{CdO}_{2}$, cadmium chloride $-\mathrm{CdCl}_{2}$ or cadmium sulfate- $\mathrm{CdSO}_{4}$ [42]. Cd is considered the seventh most toxic nonessential heavy metal [44] and enters the environment by natural sources, such as volcanism [45], and anthropogenic sources; the latter is considered the most important. Anthropogenic activities, include smelting, mining nonferrous metals, production of nonferrous metals, iron and steel and the production and disposal of Cadmium-containing materials (electroplating, pigments, stabilizers and Ni-Cd batteries) [46], use phosphate fertilizers [47], arsenic pesticides, herbicides, fungicides, plastic stabilizers, wood preservatives and others [48]. Cd can be found in all environmental compartments 
(air, soil, water and food) [46], with drinking water and food as the main human exposure routes for non-smokers and non-occupational workers [49]. Tobacco is another additional source for smokers (active and passive) [50-52]. In marine environments, Cd normally occurs in lower concentrations than in open oceans water [53] and in higher concentrations in coastal and estuarine environments due to the intensive industrial discharge, port activity and mining activity in rivers $[14,19,54]$, distributed in the sediment, particulate matter, water and marine organisms [55]. Sediments, particulate matter and water have an important role for $\mathrm{Cd}$ availability for marine organism bioaccumulation, and it depends on several factors, such as temperature, salinity (ionic strength—chloride and metals ions), size of particle, organic matter content (polyphenols, amino acids, humates, proteins), sediment ion-exchange capacity and chemical $\mathrm{Cd}$ form, among others $[55,56]$. These factors have to be taken into consideration in the sampling process of the marine organism for HM assessment. The permitted limit of $\mathrm{Cd}$ adopted by different international organizations and the detection methods in seafood are well described in Table 1.

\section{Cadmium Toxicity}

The Cd targets from seafood in humans, some of which are listed in Table 1, include bones, placenta, brain and the central nervous system [42], liver [57], cardiovascular system [58-60], immune system [61-63], reproductive systems [64] and kidneys [65]. Acute Cd toxicity by ingestion of contaminated seafood can cause the following signs and symptoms: increased salivation, choking or vomiting, abdominal pain, vertigo, loss of consciousness, painful spasm of the anal sphincter and impairment of renal function for severe toxicity $[66,67]$. From chronic toxicity, the kidney is the most affected and the symptomatic signs are the presence of low molecular weight proteins (LMWP) [68], $\beta$ 2-microglobulin ( $\beta 2-\mathrm{MG}$ ) [68], $N$-acetyl- $\beta$-d-glucosaminidase (NAG) $[68,69]$ and retinol-binding protein (RBP) [68] in the urine. These molecules are used as $\mathrm{Cd}$ biomarkers in humans [68,69]; other $\mathrm{Cd}$ biomarkers that are not validated as well as their detection methods are described in Table 1. Additionally, Cd chronic toxicity affects bones, causing fractures, severe pain, malformations [70], hypercalciuria and impaired vitamin D metabolism [71]. However, the molecular toxicity mechanism of $\mathrm{Cd}$ is not well understood. The gastrointestinal route is the main for $\mathrm{Cd}$ exposure from seafood contaminated resulting in hepatoxicity in the liver. There are two hypotheses for molecular acute toxicity of Cd: the binding to the Sulfhydryl group and the Kupffer cell activation.

From the first hypothesis, $\mathrm{Cd}$ hepatotoxicity occurs through the binding of $\mathrm{Cd}$ to sulfhydryl groups (as opposed to other groups, such as phosphate, chloride, carboxyl or amino) on critical molecules in mitochondria [72], which was verified by the protection afforded (depletion) by cysteine-rich compounds such as metallothionein (MT) [37,38] and glutathione (GSH) [39,40]. MT and GSH seem to play an important role in the hepatoprotection in acute Cd toxicity [37-39]. The inactivation of sulfhydryl groups in several molecules can result in the dysfunction of nucleic, mitochondria and endoplasmic reticulum [73], disruption of cytoskeletal organization [74,75] and disruption of the intracellular redox state [40,76] (causing oxidative stress damage to DNA [40] and lipids [40,77-80], affecting DNA synthesis [40], cell cycle regulation [73], activation of transcription factors [73] and apoptosis [81,82]).

In the second hypothesis, $\mathrm{Cd}$ activates macrophages resulting in the secretion of cytotoxic inflammatory mediators such as reactive oxygen species (ROS), reactive nitrogen species (RON), eicosanoids and platelet-activating factors and hydrolytic enzymes [73]. The ROS are well known to cause oxidative damage in important intracellular molecules (DNA, proteins and lipids) [40,77-80].

In Cd chronic exposure, the liver (hepatotoxicity) [83] is the first target organ, after which the kidneys (nephrotoxicity) $[83,84]$ and other tissues follow. In all tissues, MT is the protector of Cd toxicity since it binds to free Cd as the CdMT complex [37,38,85-88]. This complex moves to the kidneys [83,89], where it is filtered to blood [90,91] and decomposed by lysosomes liberating Cd [92], which is in turn free to exert toxicity depending on the availability of MT [93-95]. The free Cd causes toxicity by inducing oxidative stress at chronic exposure in the liver and the kidneys [34]. Cd chronic 
exposure causes carcinogenicity according to the International Agency for Research on Cancer [96] and the National Toxicology Program of the USA [97]. Cd is a human carcinogen of the group (Group 1) due to its involvement in the increased incidence of breast, lung, gastric, prostate, renal, endometrial, pancreas and kidney cancers [98-105].

\subsection{Mercury}

Mercury is the most toxic HM found in the aquatic environment. Due to its volatility, mobility and strong tendency to bioaccumulate, $\mathrm{Hg}$ receives special attention in the world [106]. Natural sources of $\mathrm{Hg}$ include primarily volcanoes, geothermal sources and topsoil enriched in mercury pertains and (from a primary source) re-emission from vegetation, land or water surfaces due to the use of land, biomass burning, meteorological conditions and gaseous mercury at air-water-soil-snow-ice exchange $[107,108]$. Combustion of fossil fuels (coal; stationary combustion) is the major anthropogenic source of mercury ( $60 \%$ of the year 2000$)$, followed by artisanal small scale gold mining, non-ferrous metals manufacturing, cement production, waste disposal and caustic soda production [109,110]. $\mathrm{Hg}$ is found in the environment in three forms, namely elemental mercury $\left(\mathrm{Hg}^{0}\right)$, inorganic mercury [mercurous- $\mathrm{Hg}_{2}{ }^{2+}$ or $\mathrm{Hg}(\mathrm{I})$ and mercuric $-\mathrm{Hg}^{2+}$ or $\mathrm{Hg}(\mathrm{II})$ ions] and organic mercury (methylmercury- $\mathrm{CH}_{3} \mathrm{Hg}^{+} \mathrm{X}^{-}$, dimethylmercury- $\left(\mathrm{CH}_{3}\right)_{2} \mathrm{Hg}$, ethylmercury- $\mathrm{CH}_{3} \mathrm{CH}_{2} \mathrm{Hg}^{+} \mathrm{X}^{-}$and phenylmercury $-\mathrm{C}_{6} \mathrm{H}_{5} \mathrm{Hg}^{+}$), with $\mathrm{X}$ being a halide, nitrate or sulphate $[111,112] . \mathrm{Hg}^{0}$ has high vapor pressure and relatively low solubility in water [111,113], and because of that, it is not the predominant marine aquatic environment. Inorganic mercury species are most soluble in water [113] and have a considerable affinity with organic and inorganic species containing sulfur in their structure (most common in the environment are mercuric sulphide- $\mathrm{HgS}$, mercuric oxide- $\mathrm{HgO}$ and mercuric chloride $-\mathrm{HgCl}_{2}[111,114]$. The most toxic and common mercury compound in the marine aquatic food chain (fishes and invertebrates, among others) is methylmercury (MHg) [115] due to its particular ability to cross the blood-brain barrier [116]. MHg is considerably accumulated as complex MeHgCys (cysteine from peptides or proteins [117] in muscle over a long time [111,112] with differences in bioavailability, tissue distribution and toxicity from methylmercury species from each marine animal [117]. The permitted limits of $\mathrm{Hg}$ in seafood are listed in Table 1 as well as the detection methods for $\mathrm{Hg}$ monitoring in seafood.

\section{Methyl Mercury Toxicity (from Seafood)}

In humans, $\mathrm{MeHg}$ consumed from seafood is absorbed in the gastrointestinal tract and later transported to the blood. The main Hg toxicity target organs [116] are the kidneys [35,118] and brain [118-120]. The symptoms from seafood exposure are chiefly observed in the central nervous system, and include, depending on the exposure, constriction of the visual field [116,121,122], sensory disturbances [121,122], ataxia [116,121,122], dysarthria [121,122], auditory disturbances and memory loss [116,121], tremor [116,121,122], sleep disturbance [116], headache [116], fatigue, difficulty concentrating [116], depression [116], diminished fine motor coordination [116], muscle and joint pain [116,122], gastrointestinal upset [116], hair thinning [116], heart rate disturbance [116], hypertension [116], numbness or tingling around the mouth [116], coma and death [112,123]

The molecular toxicity of $\mathrm{MeHg}$ seems to be well known and occurs by binding to the sulfhydryl-containing molecules (forming stable complexes) causing structural and functional modifications. Reported sulfhydryl-containing molecules include glutathione, cysteine, homocysteine, $\mathrm{N}$-acetylcysteine, metallothionein and albumin, among others, which bind to $\mathrm{MeHg}$ in the order of $10^{15}$ to $10^{20}$ [124]. The formation of the complex MeHg-GSH [125] not only reduces the availability of GSH to act as an antioxidant defense (inducing oxidative stress) but also facilitates $\mathrm{Hg}$ to gain access across cell membranes through amino acid MT transporters [125-127]. Another molecule involved in $\mathrm{Hg}$ toxicity by binding (inhibiting) to sulfhydryl group is thioredoxin reductase, which is critical for cellular stress response, protein repair and protection against oxidative damage including lipid peroxidation [128,129]. 
MeHg Chronic exposure causes teratogenicity [130-132] and carcinogenicity [133], expressing itself in progeny in the form of congenital malformations and development of tumors, respectively [134]. The data of $\mathrm{Hg}$ carcinogenicity are controversial, with some studies that have demonstrated $\mathrm{Hg}$ carcinogenicity (DNA damage) and others without evidence [134-137].

\subsection{Lead}

Lead occurs naturally combined with two or more other elements to form lead compounds sources [138]. Mining and smelting, soldering, battery manufacturing, ammunition, metal water pipes, paint and petrol are reported as anthropogenic sources [138,139]. However, actions have been carried out in many parts of the world to reduce the harmful effects of $\mathrm{Pb}$ on people and animals, such as the use of unleaded fuel and bullets and shot as well as in fishing sinkers, among other taken actions [138]. $\mathrm{Pb}$ occurs in the environment both organic and inorganic forms with oxidation states of +2 and +4 (Table 1), with inorganic lead being more predominant as $\mathrm{Pb}$ (II) [138].

However, organic lead is the most toxic lead form and the reported organic lead includes TtEL [138]. One of the main current human exposure of $\mathrm{Pb}$ occurs via drink water and food from different sources including marine animal (seafood), among other [138]. In the marine food chain, $\mathrm{Pb}$ is bio concentrated and not biomagnified due to its involvement in calcium turn-over in vertebrates resulting in its accumulation in the bones than in the soft tissues $[138,140]$. Lead uptake by fish reaches equilibrium only after chronic exposure [138]. The most reported lead species in marine organisms include inorganic lead (PbII), trimethyl lead, $X$-halide (Cl) (TML) and trimethyl lead (TEL) (Table 1) [141-143]. The human biomarkers of $\mathrm{Pb}$ poisoning and their detection methods permitted of the control of the amount of $\mathrm{Pb}$ in seafood; analytical detection methods are described in Table 2.

\subsection{Lead Toxicity}

The main target organs/systems of $\mathrm{Pb}$ compounds include the digestive system [144], bones [145], reproductive system [146-150], central and peripheral nervous system [151-154], kidney [154-158] and immunologic system [159-161]. Acute $\mathrm{Pb}$ toxicity after ingestion of contaminated seafood usually occurs in brain and kidney, and its absorption in the gastrointestinal tract [162] is influenced by nutritional calcium and iron status and age (children adsorb more, and consequently, are more vulnerable than adults) of exposed humans and solubility and lead species, among others [138]. After absorption, $\mathrm{Pb}$ is transported to other organs/systems by the bloodstream, after which it accumulates in blood, soft tissues and bones [163-167]. Acute $\mathrm{Pb}$ poisoning symptoms in humans can be grouped in (1) nervous systems dysfunction: poor attention span, headaches, irritability, loss of memory and dullness for adult and acute encephalopathy (persistent vomiting, ataxia, seizures, papilledema, impaired consciousness and coma) for infants [168-180], (2) renal dysfunction: dysfunction of the proximal tubules, manifesting as aminoaciduria, glycosuria, phosphaturia with hypophosphatemia, increased sodium and decreased uric acid excretion, progressive interstitial fibrosis, a reduction in the glomerular filtration rate and azothemia $[168,169,181]$. Hypertension is another sign of $\mathrm{Pb}$ poisoning $[169,182,183]$.

Molecular toxicity of $\mathrm{Pb}$ seems to be well understood and occurs at a concentration as low as $5 \mu \mathrm{g} / \mathrm{dl}$ of blood. $\mathrm{Pb}$ inhibits three crucial enzymes for humans' body functionating, namely delta-aminolevulinic acid dehydratase, delta-aminolevulinic acid synthase and ferrochelatase [41]. Delta-aminolevulinic acid is involved in the synthesis of porphobilinogen (PBG), which plays an important role on the biosynthesis hemeproteins (hemoglobin, myoglobin, cytochromes, guanylate cyclase and nitric oxide synthase) [184], while ferrochelatase catalyzes the incorporation of iron into the porphyrin ring $[169,185]$. The inhibition of these heme synthesis enzymes can cause a reduction in the circulating levels of hemoglobin and the inhibition of cytochrome P 450-dependent phase I metabolism [185].

The animal model tests report that at chronic exposure, $\mathrm{Pb}$ causes neurotoxicity, neurodevelopmental toxicity [186,187], cardiotoxicity [188,189], nephrotoxicity [190], genotoxicity 
(increase in DNA strand breaks) [187] and carcinogenicity (inorganic lead as probably carcinogenic to humans-Group 2A) in the kidneys [187].

\section{Heavy Metals Poisoning Treatment}

The symptomatic treatment of HM poisoning is very limited and consists generally of HM remotion using metal chelating agents. Ethylenediamine tetra-acetic acid via intravenous administration [191] or hemodialysis to remove $\mathrm{Cd}$ by urinary excretion or dialysate in case of severe toxicity (renal dysfunction) [192] or oral administration of dimercaptosuccinic acid [193] is the most commonly used for Cd poisoning. Diethyldithiocarbam ate [194], 2,3-dimercaptosuccinic acid [195] and EDTA calcium disodium [196] have also been reported as chelating agents for Cd poisoning treatment.

$\mathrm{MeHg}$ poisoning treatment involves the use of chelating agents containing sulfhydryl group in their structure by different methods, such as hemodialysis administration of penicillamine [197] and sodium 2,3-dimercapto-1-propanesulfonate(DMPS) [198] in case of renal failure. DMPS is also administrated orally [198], intravenously and nasogastrically [199], and often in combination with vitamin E [197]. 2,3-dimercaptopropanol via intramuscular administration has also been reported for Hg poisoning treatment [200]. Lead poisoning treatment is performed using chelating agents accompanied with nutritional interventions of iron and calcium supplementation [181], since iron is involved in the functioning of ferrochelatase (important enzyme for biosynthesis of hemeproteins), which is impaired by $\mathrm{Pb}$, while calcium was tuned over by $\mathrm{Pb}$; hence, there is a need to be reset during the treatment. The reported use of chelating agents for $\mathrm{Pb}$ poisoning treatment include intramuscular administration of dimercaprol with an oil solution due to its weak solubility in water (dimercaprol avoid encephalopathy) [168,201], Calcium Disodium EDTA, which is administrated after dimercaprol to avoid the increasing lead concentration in the central nervous system [201], and oral administration of 2,3-meso-dimercaptosuccinic acid [201]. 
Table 2. Cadmium, mercury, lead and arsenic biomarkers: RBP—retinol-binding protein; LMWP-low molecular weight protein; $\beta 2-\mathrm{MG}$ - $\beta 2$-microglobulin; NAG-N-acetyl- $\beta$-d-glucosaminidase (NAG); $\alpha$-GST-alpha- S-transferase; VDBP-vitamin D-binding protein; $\alpha 1-M G-a l p h a \quad 1-m i c r o g l o b u l i n ;$ 8-OH-G—8-hydroxyguanine; KIM-1—kidney injury molecule-1; cDNA—deoxyribonucleic acid; MT—metallothionein; GASTA1—anti-glutathione S-transferase alpha; $\mathrm{Pb}-\mathrm{U},-\mathrm{P}$, -B—lead concentration in urine, plasma, and blood; ALAD— $\delta$-aminolevulinic acid dehydratase; ALA-P,-B,-U - $\delta$-aminolevulinic acid in plasma, blood, and urine; $\mathrm{CP}-\mathrm{B}$. - $\mathrm{P}$-coproporphyrin in blood and plasma; $\mathrm{P} 5^{\prime} \mathrm{N}$ - pyrimidine nucleotidase; NADS - nicotinamide adenine dinucleotide synthase; $\mathrm{ZP} —$ zinc protoporphyrin and detection methods:CVAAS—cold vapor atomic absorption spectrometry; GFASS—graphite furnace AAS; ICP—MS—inductively coupled plasma mass spectrometry; FAAAS—flame AAS; ICP-AES—ICP atomic emission spectrometry; CM—colorimetric method; RGSS—radioactivity gamma scintillation spectrometer; EIA — enzyme immune assay; EU—European Union; USEPA—United States Environmental Protection Agency; FAOUN—Food and Agriculture Organization of the United Nations, tHg — total mercury; MeHg-methylmercury; MeHgMe-dimethyl mercury; ANHMRC—Australian National Health and Medical Research Council; ANZFSC—Australia New Zealand Food Standards Code; EtHg—Ethyl mercury; iHg—inorganic mercury; HPLC-UVD and - ECD—high performance liquid chromatograph with ultra- violet detection or with electrochemical detection; DPSAV-differential pulse stripping anodic voltammetry; Cd-HRA—cadmium-hemoglobin radioassay; CF-cytofluorimetry; CD—cluster of differentiation; IC-PICVGAFS-ion chromatography using photo-induced chemical vapor generation atomic fluorescence spectrometric; TDA-AAS-thermal decomposition amalgamation AAS; SM-spectroscopy methods; SPME-GC-FAPES-solid phase microextraction in conjunction with tandem gas chromatography-furnace atomization plasma emission spectrometry; IMGC-AE-isothermal multicapillary gas chromatography with atomic emission detection; CGC-pyro-AFS-capillary gas chromatography coupled to an atomic fluorescence detector via pyrolysis; GC-AES—gas chromatography-atomic emission spectrometry; ESR—electron spin resonance; FP—fluorescent probes; ELIA—enzyme-linked immunosorbent assay; CGCAAS—glass capillary gas chromatography AAS; PPA—profiling protoarray; XRFS—X-ray fluorescence spectroscopy; ETAAS—electrothermal AAS; AE—acid extraction, DD—detergent dilution, NSE—neutral solvent extraction, HF-hematofluorimetry; RCMP—radioactive cytidine 5'-monophosphate; PM—photometric method; LC-(PO)-HG-AFS-liquid chromatography-photo-oxidation-hydride generation-atomic fluorescence spectrometry; HG-AAS-hydride generation-atomic absortion spectrometry; EC-ICP-MS—exchange chromatography ICP-MS; CEHPLC-ICP-MS—cation-exchange HPLC-ICP-MS; CA—Comet assay.

\begin{tabular}{|c|c|c|c|c|c|c|c|}
\hline \multirow{2}{*}{ Metal } & \multirow{2}{*}{ Biomarkers in Humans } & \multirow{2}{*}{ Biomarkers Detection } & \multicolumn{2}{|c|}{ Limit in Seafood, $\mathrm{mgKg}^{-1}$} & \multicolumn{3}{|c|}{ Detection Method in Seafood } \\
\hline & & & Tissue & Value & Technique & LOD, $\mu \mathrm{gKg}^{-1}$ & LOQ, $\mu \mathrm{gKg}^{-1}$ \\
\hline \multirow{5}{*}{$\mathrm{Cd}$} & 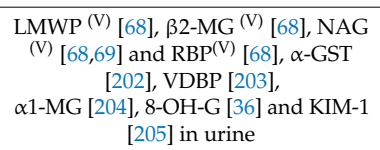 & $\begin{array}{c}\text { CA }[36,68,69,202-205] \text { and EIA } \\
{[36,68,69,202-205]}\end{array}$ & Fish muscle & 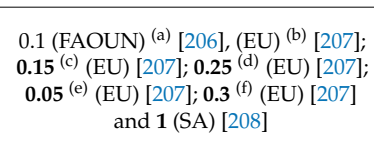 & ICP-MS [209-211] & $1-30$ [209-211] & $4-10.1[209,210]$ \\
\hline & $\begin{array}{l}\text { Oxidative stress biomarker } \\
\text { in blood [32] }\end{array}$ & HPLC -UVD and -ECD [32] & \multirow{2}{*}{$\begin{array}{l}\text { Crustacean muscle and } \\
\text { abdomen (excluding brown } \\
\text { meat of crab) }\end{array}$} & \multirow[t]{2}{*}{0.5 (FAOUN) [206] and (EU) [207] } & ICP-AES [212] & & \\
\hline & \multirow[b]{2}{*}{$\begin{array}{l}\text { Genomic/proteomic (hsp90) responses } \\
\text { in bronchiolar lavage materials cells } \\
\text { [213] and Cd-induction of MT in } \\
\text { human tumor cell line HepG2 [214] }\end{array}$} & \multirow[b]{2}{*}{$\begin{array}{l}\text { cDNA microarray } \\
\text { analysis [213] and } \\
\text { Cd-HRA [214] }\end{array}$} & & & FAAS $[14,19,54,215]$ & & \\
\hline & & & $\begin{array}{c}\text { Bivalve mollusks and } \\
\text { Cephalopods } \\
\text { (without viscera) }\end{array}$ & $\mathbf{1}$ (FAOUN) [206] and (EU) [207] & DPSAV [216] & & \\
\hline & $\begin{array}{c}\text { Autophagy in human CD34+ } \\
\text { hematopoietic progenitor cells [63] }\end{array}$ & CF [63] & $\begin{array}{l}\text { Seaweed or dried } \\
\text { bivalve mollusks }\end{array}$ & 3 (EU) [207] & ETAAS [217] & $0.045[217]$ & $0.015[217]$ \\
\hline
\end{tabular}


Table 2. Cont.

\begin{tabular}{|c|c|c|c|c|c|c|c|}
\hline \multirow{2}{*}{ Metal } & \multirow{2}{*}{ Biomarkers in Humans } & \multirow{2}{*}{ Biomarkers Detection } & \multicolumn{2}{|c|}{ Limit in Seafood, $\mathrm{mgKg}^{-1}$} & \multicolumn{3}{|c|}{ Detection Method in Seafood } \\
\hline & & & Tissue & Value & Technique & $\mathrm{LOD}_{,} \mu \mathrm{gKg}^{-1}$ & $\mathrm{LOQ}^{\mu \mathrm{gKg}^{-1}}$ \\
\hline \multirow{4}{*}{$\mathrm{Hg}$} & $\begin{array}{c}\text { Porphyrins [218]; Hg level(exposure } \\
\text { to Hgo [219]; GSH depletion [35]; } \\
\text { MT induction [220]; Renal } \\
\text { dysfunction (presence of NAG, RBP, } \\
\alpha 1, \beta 1-\mathrm{MG}, \mathrm{Kim}-1 \text { ) [221] }\end{array}$ & $\begin{array}{l}\text { HPLC-FD [218]; CV-AAS [222]; } \\
\text { SM [35]; RGSS [220] }\end{array}$ & Fish muscle & $\begin{array}{c}\mathbf{1}(\mathrm{FAOUN}) \text { [206], (SA) [208] and (UE) } \\
\text { [207] 0.3 (China) [223]; 0.5 (UE) } \\
\text { [207]; 0.4 (Japan) [224] }\end{array}$ & CVAAS (tHg) [215,224-228] & $0.2-4600(\mathrm{tHg})[215,224-228]$ & $\begin{array}{c}2-9.9(\mathrm{tHg}) \\
{[215,224-228]}\end{array}$ \\
\hline & $\begin{array}{l}\text { GSH depletion [229]; } \\
\text { MT induction [230] }\end{array}$ & SM [229]; RGSS [230] & Crustaceans & $0.5^{(\mathrm{h})}(\mathrm{EU})[207]$ & $\begin{array}{l}\text { LC-ICP-MS (MHg and EHg) } \\
\text { [231]; HPLC-ICP-MS (iHg and } \\
\text { MHg) [232]; ICP-MS (tHg) } \\
\text { [209,210,231]; IC-PICVGAFS (iHg } \\
\text { and MHg) [233]; ICP-AES (tHg) } \\
\text { [212]; LC-UV-CV- AFS (iHg, tHg } \\
\text { and MHg) [234] }\end{array}$ & $\begin{array}{c}5.30[209] ; 2[210] ; 0.25(\mathrm{tHg})[231] ; \\
0.1(\mathrm{MHg})[231] ; 0.2(\mathrm{EHg})[231] ; \\
0.02(\mathrm{iHg})[232] ; 0.03(\mathrm{MHg})[232] ; \\
80,000(\mathrm{MHg} \mathrm{MHg})[233] ; 100,000 \\
(\mathrm{iHg})[233] ; 0.4(\mathrm{iHg})[234] ; 1 \\
\text { (tHg) [234]; } 0.3(\mathrm{MHg})[234]\end{array}$ & $\begin{array}{l}16.2[209], 6[210] ; \\
1.2(\mathrm{iHg})[234] ; 3 \\
\quad(\mathrm{Hg}) \\
(\mathrm{MHg})[234] ;\end{array}$ \\
\hline & $\begin{array}{l}\text { Hg level in hair [219,235] (exposure } \\
\text { to MHg) [235]; GSH depletion [119]; } \\
\text { Oxidative stress [236]; }\end{array}$ & CVAFS [235]; SM [119] & \multirow[b]{2}{*}{ Fishery products } & \multirow[b]{2}{*}{$0.5(\mathrm{EU})[207]$} & $\begin{array}{c}\operatorname{AAS}(\mathrm{tHg})[54] ; \\
\operatorname{TDA}-\mathrm{AAS}(\mathrm{tHg})[237]\end{array}$ & & $3(\mathrm{tHg})[237]$ \\
\hline & $\begin{array}{l}\text { Hg level in blood (exposure to } \\
\text { MeHg) [123]; GASTA1 increasing } \\
\text { [238] in serum }\end{array}$ & ICP-MS [33]; PPA [238] & & & $\begin{array}{l}\text { CGC-pyro-AFS (iHg and MMHg) } \\
\text { [239]; GC-AES (MHg and iHg) } \\
\text { [240]; IMGC-AE [241]; CGC-AAS } \\
\text { [242]; SPME-GC-FAPES (iHg and } \\
\text { MHg) [243] }\end{array}$ & $\begin{array}{c}1 \mathrm{pg}(\mathrm{iHg})[239] ; 2 \mathrm{pg}(\mathrm{MMHg}) \\
\text { [239]; 0.003 (MHg) [240]; } 0.0125 \\
(\mathrm{iHg})[240] ; 20(\mathrm{iHg})[241] ; 80 \\
(\mathrm{MHg})[241] ; 0.1 \mathrm{ng} \text { [242]; } 1.5 \\
(\mathrm{MHg})[243] ; 0.7(\mathrm{iHg})[243]\end{array}$ & \\
\hline \multirow{7}{*}{$\mathrm{Pb}$} & $\begin{array}{l}\text { Pb-B, Pb-U, Pb-P MPb-U and } \\
\text { MPb-P [244-249] } \\
\end{array}$ & $\begin{array}{l}\text { GFAAS [244] and ICP-MS } \\
\text { [245-249] }\end{array}$ & Fish muscle & 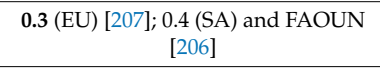 & GFASS $[225,226]$ & 1.8 [225]; 2 [226] & 6.2 [225] \\
\hline & $\begin{array}{l}\text { ALAD inhibition in the blood } \\
\text { [250-252] }\end{array}$ & PM [250] & Bivalve mollusks & $1.5(\mathrm{EU})[207]$ and 1 (FAOUN) [206] & XRFS & & \\
\hline & $\begin{array}{l}\text { CP-U and CP-B increasing } \\
\text { activity [253-255] }\end{array}$ & HPLC-MS [253-255] & Crustaceans & $0.5(\mathrm{EU})^{(\mathrm{g})}[207]$ and FAOUN [206] & ICP-MS [209-211]; ICP-AES [212] & $\begin{array}{c}2.70 \text { [209]; } 4 \text { [210]; } 10 \text { - } 240 \text { [211]; } \\
18 \text { [256] }\end{array}$ & $\begin{array}{c}8.1[209] ; 12[210] ; \\
62[256]\end{array}$ \\
\hline & ZP alteration in blood [257-266] & $\begin{array}{c}\text { AE [257,258], DD [259,260], } \\
\text { NSE }[261,262], \operatorname{HF}[261,263,264] \\
\text { and HPLC }[265,266]\end{array}$ & \multirow{4}{*}{$\begin{array}{l}\text { Cephalopods } \\
\text { (without viscera) }\end{array}$} & \multirow{4}{*}{$\mathbf{1}(\mathrm{EU})[207]$ and SA [208] } & FAAS [19,215,267]; AAS [14] & 1 [267]; & \\
\hline & $\begin{array}{l}\text { ALA-U, ALA-B and ALA-P } \\
\text { alteration [268] }\end{array}$ & HPLC-UVD [268] & & & ETAAS [217] & $0.0732[217]$ & $0.0244[217]$ \\
\hline & $\mathrm{P}^{\prime} \mathrm{N}$ alteration in blood [269-272] & $\begin{array}{c}\text { CM [269], RCMP [270] and } \\
\text { HPLC [271,272] }\end{array}$ & & & \multirow[t]{2}{*}{ DPSAV [216] } & & \\
\hline & NADS alteration in blood $[273,274]$ & HPLC [274] and EIA [273] & & & & & \\
\hline
\end{tabular}

(a) Species: Dicologoglossa mneata (Wedge sale), Anguilla anguilla (Eel), Trachurus trachurus (Horse Mackerel or Scad), Mugil labrosus labrosus (grey mullet), DipZodus vulgaris (Common two-banded seabream), Sardina pilchardus (European pilchard or sardine), Engraulis encrasicholus (European anchovy), Luuarus imperialis (Louvar or Luvar). (b) Scomber species (mackerel), Thunnus species, Katsuwonus pelamis and Euthynnus species (tuna), Sicyopterus lagocephalus (bichique). (c) Auxis species (bullet tuna). (d) Engraulis species (anchovy), Xiplhas gladius (swordfish) Sardina pilchardus (sardine). (e) For species not mentioned in (a), (b), (c) and (d). (f) Xiphias gladius (swordfish). (g) Species: Lophius species (anglerfish), Anarhichas lupus (Atlantic
(a) (swordfish) Sardina pilchardus (sardine). (e) For species not mentioned in (a), (b), (c) and (d). (f) Xiphias gladius (swordfish). (g) Species: Lophius species (anglerfish), Anarhichas lupus (Atlantic
catfish), Sarda sarda (bonito), Anguilla species (eel), Hoplostethus species (emperor, orange roughy and rosy soldierfish), Coryphaenoides rupestris (grenadier), Hippoglossus hippoglossus (halibut), catfish), Sarda sarda (bonito), Anguilla species (eel), Hoplostethus species (emperor, orange roughy and rosy soldierfish), Coryphaenoides rupestris (grenadier), Hippoglossus hippoglossus (halibut),
Makaira species (marlin), Lepidorhombus species (megrim), Mullus species (mullet), Esox lucius (pike), Orcynopsis unicolor (plain bonito), Tricopterus minutes (poor cod), Centroscymnus Makaira species (marlin), Lepidorhombus species (megrim), Mullus species (mullet), Esox lucius (pike), Orcynopsis unicolor (plain bonito), Tricopterus minutes (poor cod), Centroscymnus
coelolepis (Portuguese dogfish), Raja species (rays), Sebastes marinus, S. mentella, S. viviparus (redfish), Istiophorus platypterus (sailfish), Lepidopus caudatus and Aphanopus carbo (scabbard fish), Pagellus species (seabream and pandora), shark (all species), Lepidocybium flavobrunneum and Ruvettus pretiosus, Gempylus serpens (snake mackerel or butterfish), Acipenser species (sturgeon), Xiphias gladius (swordfish) and Thunnus species, Euthynnus species, Katsuwonus pelamis (tuna). (h) excluding the brown meat of crab and head and thorax meat of lobster and similar large crustaceans (Nephropidae and Palinuridae) 


\section{Concentration of Cadmium, Mercury and Lead in Seafood from African Countries of the Indian Ocean and the Red Sea}

The marine environment of the Indian Ocean and the Red Sea has many sources of HM due to human activities such as port activity, mining (metals, gas, and petroleum) activity, discharges of untreated domestic residues and contaminated river water with HM where precious metals and rocks are explored and produced (Table 3) [11-25]. HM can get into humans through diet, which can suppose a risk for health. The $\mathrm{HM}$ that constitute a great threat to public health includes $\mathrm{Pb}, \mathrm{Hg}$ and $\mathrm{Cd}$, which are potent toxicants to humans. The bioaccumulation of these metals in tissues of seafood leads to intoxication causing decreased fertility, cellular and tissue damage, cell death and dysfunction of a variety of organs and death [11-25]. Figure 1 describes the sources of HM in the African countries bordering the Indian Ocean and the Red Sea. Many countries adopted WHO legislation to control and monitor the presence of HM in seafood. There are no data of seafood poisoning caused by HM; this lack does not necessarily implicate the absence of poisoning incidents. Rather, the lack of an operational monitoring program, training staff for recognizing of HM poisoning symptoms and equipped laboratory could partially explain the lack of HM seafood poisoning data.

Table 3. Main sources of HM and countries with a monitoring program in the African countries bordering the Indian Ocean and the Red Sea.

\begin{tabular}{|c|c|c|}
\hline Country & Local & HM Source \\
\hline Egypt & Gulf of Suez [14] and Red Sea [14,275-281] & Drilling fluids in oil fields, tourism and port activities [14,275-281] \\
\hline Sudan & Sawaki and Port-Sudan [282] & Port activities [282] \\
\hline Eritrea & Assed and Massawa Ports & Port activities \\
\hline Djibouti & $\begin{array}{c}\text { Gulf of } \\
\text { Tadjourah [283] }\end{array}$ & Port activities [283] \\
\hline Somalia & $\begin{array}{c}\text { Barawa, Berbera, Bosaso, Eyl, El-Mana, Eyl, Hobyo, } \\
\text { Kismaayo, Las Khorey, Mareeg, Merca, Mogadishu, } \\
\text { Qandala, Ras Kamboni and Zeila }\end{array}$ & Port activities \\
\hline Kenya & Watamu, Mombassa and Kilindini harbors & Port and tourism activities $[284,285]$ \\
\hline Tanzania & $\begin{array}{l}\text { Mwamba Nyama, Mwamba } \\
\text { Wamba, Tanga, Zanzibar, Mbegani and the Dar es } \\
\text { Salaam harbors }\end{array}$ & $\begin{array}{c}\text { Port activities [286] and storm } \\
\text { water runoff from the city roads and } \\
\text { garages as a result of the previous usage } \\
\text { of leaded petrol [23] }\end{array}$ \\
\hline Madagascar & $\begin{array}{c}\text { Antsiranana, Mahajanga, Morondava, Toamasina, } \\
\text { Tolagnaroand Toliara Ports }\end{array}$ & Port activities \\
\hline \multirow{2}{*}{ Mozambique } & Maputo and Nacala Ports & Port activities \\
\hline & Rovuma River Basin & Gas production activities \\
\hline South Africa & $\begin{array}{l}\text { Durban, Elisabeth, Richards Bay, Mossel Bay, Ngqura, } \\
\text { East London and Cape Town harbors }\end{array}$ & Port activities [287] \\
\hline
\end{tabular}

The incidence of HM is provided in Table 4. In general, all African countries of the Indian Ocean and the Red Sea have enough laboratory conditions to determine the concentration of HM in seafood in the universities and fishery research centers. The concentration of HM in seafood ranges from 0.004 to 49.65 [14,288] and 0.01 to $18.5 \mathrm{mgKg}^{-1}$ [2,284] in the Indian Ocean and the Red Sea, respectively, with most data being concentrated in the Red Sea. Along this geographic area, the main HM sources include ports and gas/petroleum production activities, with the Red Sea having more ports on both coasts, African and Saudi Arabian. Some seafood from the African Red Sea coas,t such as mollusks Ruditapes decussatus, Venerupis pullastra [281], Psammobia depressa, Brachidontes sp., Nerita waigiensis, Patella miniata, Lepidochiton cinereus, Morula squamosa, Tridacna squamosa, Morula squamosal [289] Barbatus barbatus and Patella caerulea [19], have presented $\mathrm{Cd}$ and Pb concentrations higher than the permitted limit by FAOUN/EU regulations ( $>1$ and $1.5 \mathrm{mgKg}^{-1}$, respectively, for fish and shellfish) [206]. Rhizoprionodon acutus presented the highest content of $\mathrm{Hg}$ in its muscle; this species is one of the recommended to be used for HM monitoring in the marine environment [288]. Fish species, namely Epinephelus sp., Sardinella sp., Synodus sp., Nemipterus japonicus, Carangoides 
bajad, Lutjanus bohar and Gerres oyena [290], have also presented higher $\mathrm{Cd}$ and $\mathrm{Pb}$ contents in their muscles $\left(>0.3\right.$ and $\left.0.4 \mathrm{mgKg}^{-1}\right)$ than permitted by FAOUN/EU regulations [206]. On the Indian Ocean coast, certain species of fish, namely Sardinella gibbosan, Leiognathus equula, Upeneus spp., Lutjanus fulviflamma, Sphraena jello muscle, Monodactylus argenteus, Secutor insidiator, Mugil mugil, Carangoides gymnostethus, Geres oyena, Crenidens crenidens, Chorinemus tol, Leptoscarus vaigiensis, Spilotichthys pictus, Siganus sutor, Lenthrinus sp., Therapon jarbu and Anadara antiquata, bioaccumulated higher Pb contents in their muscles, with the maximum concentration found $18.5 \mathrm{mgKg}^{-1}[284,291]$. Other fish species, namely Xiphias gladius, Thunnu,s albacares, Katsuwonus pelamis, Coryphaena hippurus, Xiphias gladius, Thunnus albacares and Coryphaena hippurus, bioaccumulated the highest $\mathrm{Hg}$ content, ranging from 0.56 to $3.97 \mathrm{mgKg}^{-1}$ [292], higher than the legal limit $\left(0.5 \mathrm{mgKg}^{-1}\right)$ [206]. Invertebrates species such as Octopus cyanea and Saccostrea cucullate from the Tanzanian coast presented Pb contents below the permitted limit $[23,286]$. The highest $\mathrm{Hg}$, $\mathrm{Pb}$ and $\mathrm{Cd}$ content were found in bivalve mollusk Mytilus galloprovincialis from the South African coast [287]. The High HM content found in different species for human consumption evidence a threat to public health.

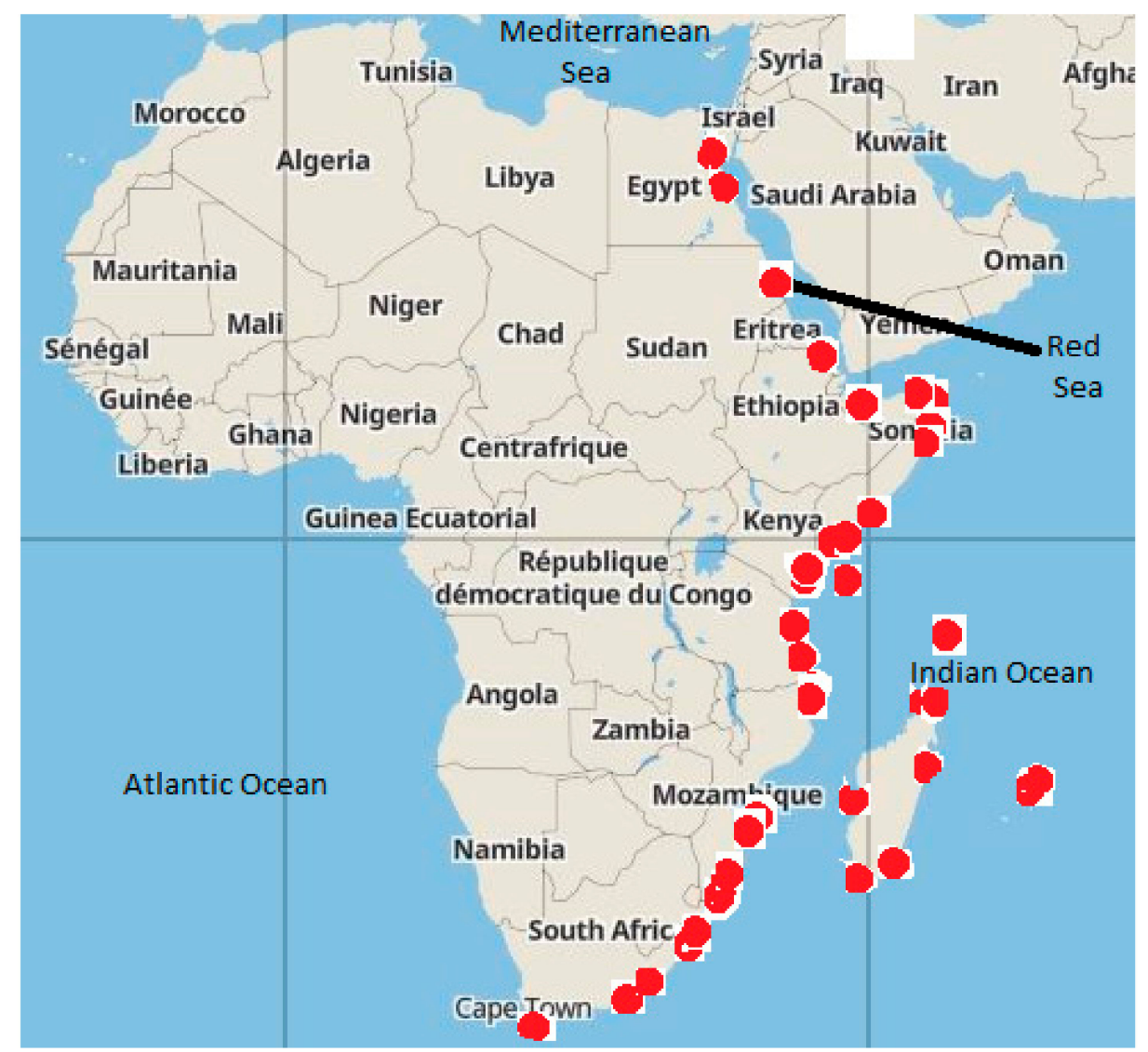

Figure 1. Locals (sites) of main sources of heavy metal in the African coasts of the Indian Ocean and the Red Sea. In these locales, there is port activity, tourism and petroleum activities. 
Table 4. Concentration of cadmium, mercury and lead in seafood from African countries bordering the Indian Ocean and the Red Sea.

\begin{tabular}{|c|c|c|c|c|c|c|c|}
\hline Country & Local & Date & Seafood & Heavy Metal & Concentration, $\mathrm{mgKg}^{-1}$ & Detection & Reference \\
\hline \multirow{31}{*}{ Egypt } & \multirow{2}{*}{ Hourghada, Suez and Ismaila } & \multirow{2}{*}{ 1986-1989 } & \multirow{2}{*}{ Unknown fish species } & $\mathrm{Cd}$ & 1.24 & \multirow{2}{*}{ AAS } & \multirow{2}{*}{ [293] } \\
\hline & & & & $\mathrm{Pb}$ & 0.82 & & \\
\hline & \multirow{2}{*}{ Gulf of Suez } & \multirow{6}{*}{2004} & \multirow{6}{*}{$\begin{array}{c}\text { Tridacna } \\
\text { Maxima shell } \\
\text { (bivalve } \\
\text { mollusk) }\end{array}$} & $\mathrm{Cd}$ & 35.83 & \multirow{6}{*}{ AAS } & \multirow{6}{*}{ [14] } \\
\hline & & & & $\mathrm{Pb}$ & 1.79 & & \\
\hline & \multirow{2}{*}{ Hurghada harbor } & & & $\mathrm{Cd}$ & 44.65 & & \\
\hline & & & & $\mathrm{Pb}$ & 1.76 & & \\
\hline & \multirow{2}{*}{ El-Esh } & & & $\mathrm{Cd}$ & 39.45 & & \\
\hline & & & & $\mathrm{Pb}$ & 1.65 & & \\
\hline & \multirow{3}{*}{ Suez } & \multirow{6}{*}{2014} & \multirow{6}{*}{ Erugosquilla massavensis muscle (crustacean) } & $\mathrm{Hg}$ & 4.91 & \multirow{6}{*}{ AAS } & \multirow{6}{*}{ [294] } \\
\hline & & & & $\mathrm{Pb}$ & 11.49 & & \\
\hline & & & & $\mathrm{Cd}$ & 0.57 & & \\
\hline & \multirow{3}{*}{ Ismailia } & & & $\mathrm{Hg}$ & 4.00 & & \\
\hline & & & & $\mathrm{Pb}$ & 9.70 & & \\
\hline & & & & $\mathrm{Cd}$ & 0.44 & & \\
\hline & \multirow{4}{*}{ Lake Timsah } & \multirow{4}{*}{ 2006-2007 } & \multirow{2}{*}{ Ruditapes decussatus soft tissue (mollusk) } & $\mathrm{Cd}$ & 5.00 & \multirow{4}{*}{ FAAS } & \multirow{4}{*}{ [281] } \\
\hline & & & & $\mathrm{Pb}$ & 16.50 & & \\
\hline & & & \multirow{2}{*}{ Venerupis pullastra soft tissue (mollusk) } & $\mathrm{Cd}$ & 9.30 & & \\
\hline & & & & $\mathrm{Pb}$ & 19.00 & & \\
\hline & \multirow{13}{*}{ Gulf of Suez } & \multirow{13}{*}{2009} & Patella nigrolineata soft tissue (bivalve mollusk) & $\mathrm{Hg}$ & 0.11 & & \\
\hline & & & & $\mathrm{Pb}$ & 1.03 & & \\
\hline & & & Ostrea crestata soft tissue (bivalve mollusk) & $\mathrm{Cd}$ & 0.31 & & \\
\hline & & & & $\mathrm{Hg}$ & 0.03 & & \\
\hline & & & & $\mathrm{Pb}$ & 0.35 & & 520 \\
\hline & & & Tridacna squamosa soft tissue (bivalve mollusk) & $\mathrm{Cd}$ & 0.36 & FAAS & {$[289]$} \\
\hline & & & & $\mathrm{Hg}$ & 0.01 & & \\
\hline & & & & $\mathrm{Pb}$ & 14.48 & & \\
\hline & & & Nerita waigiensis soft tissue (bivalve mollusk) & $\mathrm{Cd}$ & 0.37 & & \\
\hline & & & & $\mathrm{Hg}$ & 0.03 & & \\
\hline & & & & $\mathrm{Pb}$ & 1.50 & & \\
\hline & & & Lepidochiton cinereus soft tissue (bivalve mollusk) & $\mathrm{Cd}$ & 0.35 & & \\
\hline & & & & $\mathrm{Hg}$ & 0.02 & & \\
\hline
\end{tabular}


Table 4. Cont

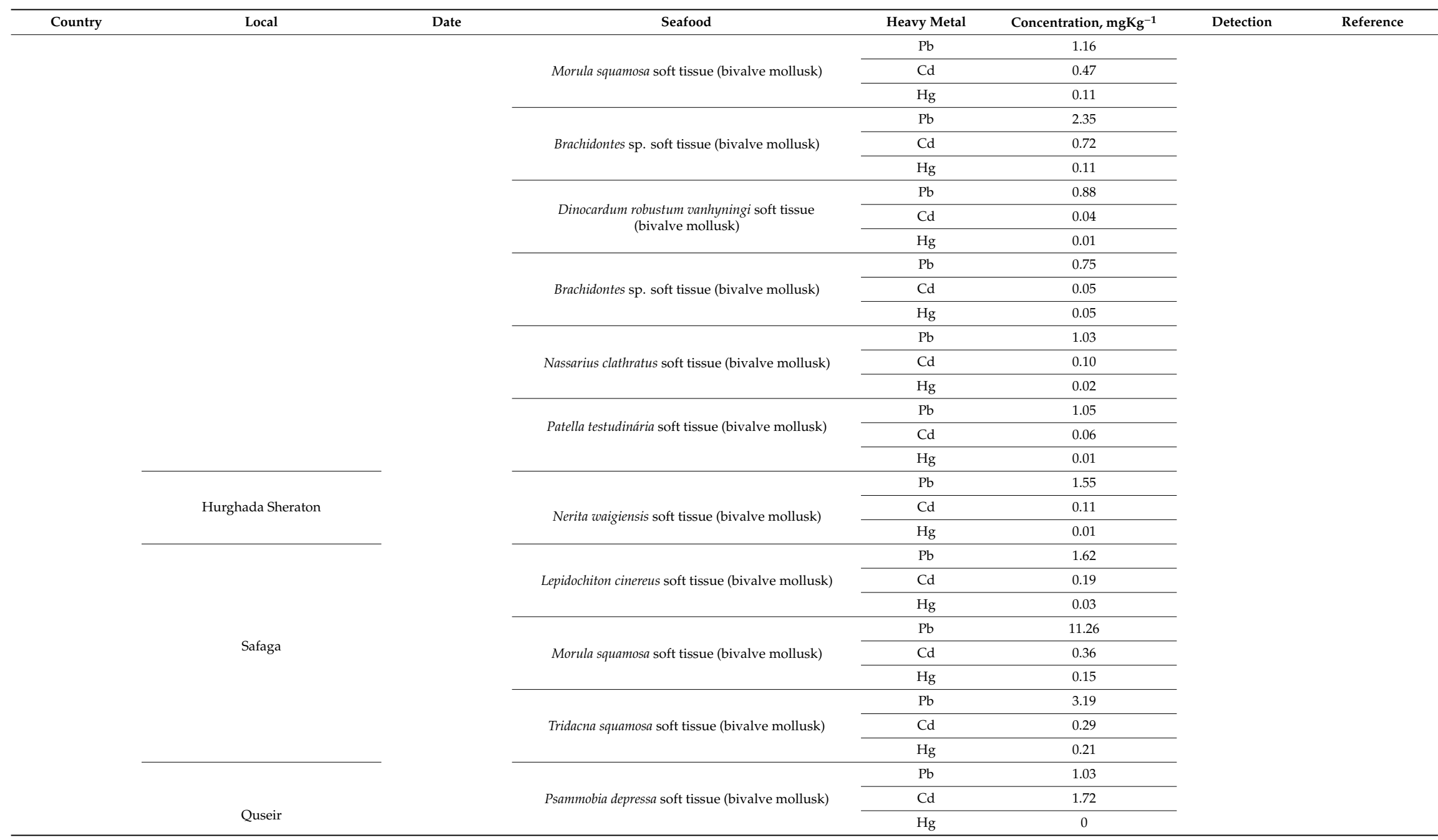


Table 4. Cont.

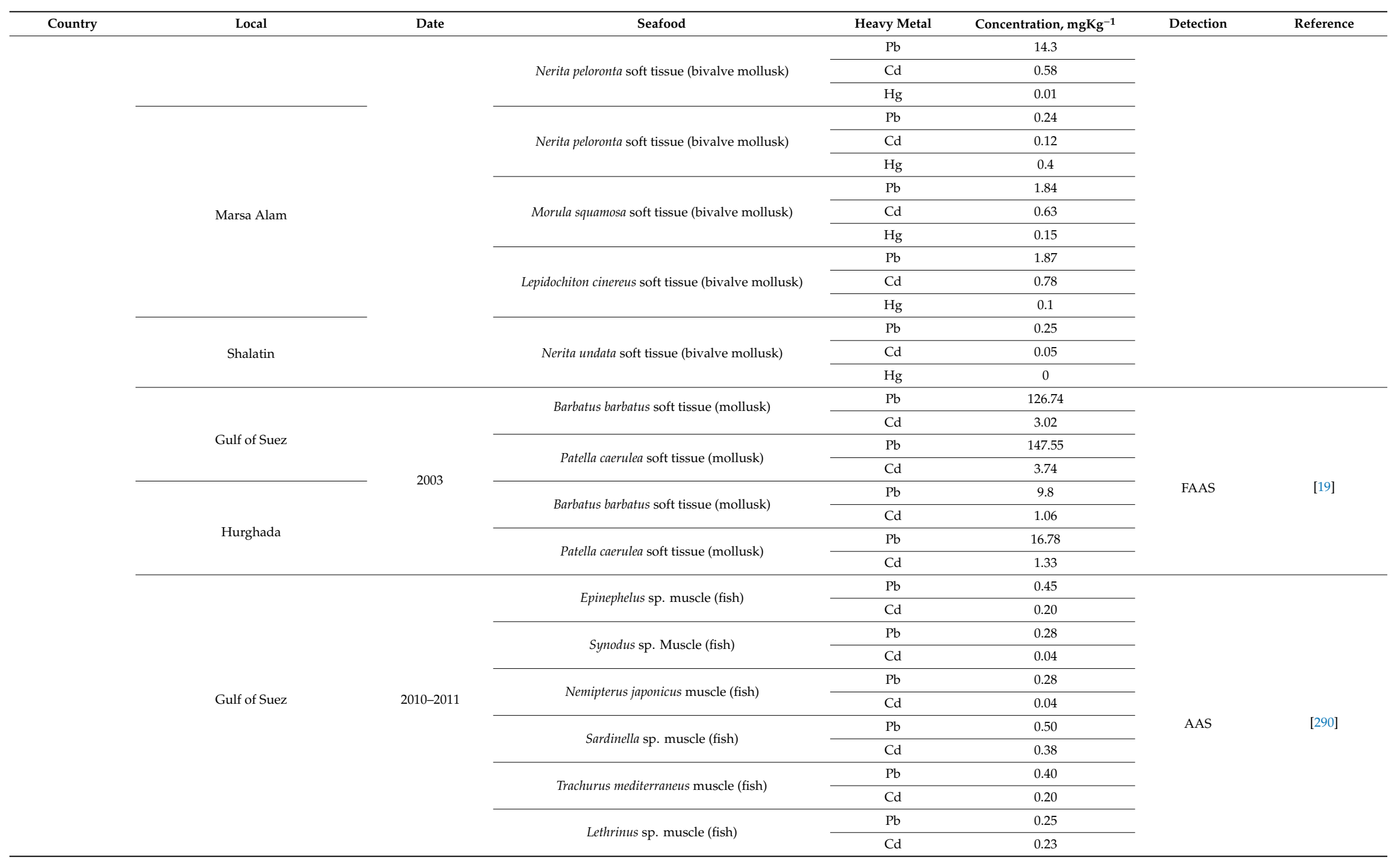


Table 4. Cont.

\begin{tabular}{|c|c|c|c|c|c|c|c|}
\hline Country & Local & Date & Seafood & Heavy Metal & Concentration, $\mathrm{mgKg}^{-1}$ & Detection & Reference \\
\hline & \multirow{19}{*}{ Shalateen } & & \multirow{2}{*}{ Epinephelus sp. muscle (fish) } & $\mathrm{Pb}$ & 0.88 & & \\
\hline & & & & $\mathrm{Cd}$ & 0.12 & & \\
\hline & & & \multirow{2}{*}{ Caranx sp. muscle (fish) } & $\mathrm{Pb}$ & 0.28 & & \\
\hline & & & & $\mathrm{Cd}$ & 0.07 & & \\
\hline & & & \multirow{2}{*}{ Scarus gibbus muscle (fish) } & $\mathrm{Pb}$ & 0.21 & & \\
\hline & & & & $\mathrm{Cd}$ & 0.03 & & \\
\hline & & & \multirow{2}{*}{ Synodus sp. muscle (fish) } & $\mathrm{Pb}$ & 0.51 & & \\
\hline & & & & $\mathrm{Cd}$ & 0.07 & & \\
\hline & & & \multirow{2}{*}{ Nemipterus japonicus muscle (fish) } & $\mathrm{Pb}$ & 0.46 & & \\
\hline & & & & $\mathrm{Cd}$ & 0.06 & & \\
\hline & & & \multirow{2}{*}{ Carangoides bajad muscle (fish) } & $\mathrm{Pb}$ & 0.52 & & \\
\hline & & & & $\mathrm{Cd}$ & 0.08 & & \\
\hline & & & \multirow{2}{*}{ Lutjanus bohar muscle (fish) } & $\mathrm{Pb}$ & 0.51 & & \\
\hline & & & & $\mathrm{Cd}$ & 0.08 & & \\
\hline & & & \multirow{2}{*}{ Thunnus albacares muscle (fish) } & $\mathrm{Pb}$ & 0.32 & & \\
\hline & & & & $\mathrm{Cd}$ & 0.06 & & \\
\hline & & & \multirow{2}{*}{ Gerres oyena muscle (fish) } & $\mathrm{Pb}$ & 0.41 & & \\
\hline & & & & $\mathrm{Cd}$ & 0.11 & & \\
\hline & & & Sargocentron spiniferum muscle (fish) & $\mathrm{Cd}$ & 0.06 & & \\
\hline & \multirow{10}{*}{ Hurghada } & & \multirow{2}{*}{ Epinephelus sp. muscle (fish) } & $\mathrm{Pb}$ & 0.45 & & \\
\hline & & & & $\mathrm{Cd}$ & 0.05 & & \\
\hline & & & \multirow{2}{*}{ Caranx sp. muscle (fish) } & $\mathrm{Pb}$ & 0.25 & & \\
\hline & & & & $\mathrm{Cd}$ & 0.05 & & \\
\hline & & & \multirow{2}{*}{ Scarus gibbus muscle (fish) } & $\mathrm{Pb}$ & 0.24 & & \\
\hline & & & & $\mathrm{Cd}$ & 0.03 & & \\
\hline & & & \multirow{2}{*}{ Sardinella sp. muscle (fish) } & $\mathrm{Pb}$ & 0.25 & & \\
\hline & & & & $\mathrm{Cd}$ & 0.07 & & \\
\hline & & & \multirow{2}{*}{ Siganus rivulatus muscle (fish) } & $\mathrm{Pb}$ & 0.04 & & \\
\hline & & & & $\mathrm{Cd}$ & 0.05 & & \\
\hline
\end{tabular}


Table 4. Cont.

\begin{tabular}{|c|c|c|c|c|c|c|c|}
\hline Country & Local & Date & Seafood & Heavy Metal & Concentration, $\mathrm{mgKg}^{-1}$ & Detection & Reference \\
\hline \multirow{6}{*}{ Djibouti } & \multirow{6}{*}{ Gulf of Tadjoura } & \multirow{6}{*}{ 2016-2018 } & \multirow{4}{*}{ Sphyrna lewini (shark) } & $\mathrm{Cd}$ & 0.48 & \multirow{6}{*}{ ICP - MS } & \multirow{6}{*}{ [288] } \\
\hline & & & & $\mathrm{Hg}$ & 12.51 & & \\
\hline & & & & $\mathrm{Pb}$ & 0.08 & & \\
\hline & & & & $\mathrm{Cd}$ & 14.50 & & \\
\hline & & & \multirow[t]{2}{*}{ Rhizoprionodon acutus (shark) } & $\mathrm{Hg}$ & 0.68 & & \\
\hline & & & & $\mathrm{Pb}$ & 0.16 & & \\
\hline \multirow{29}{*}{ Kenya } & \multirow{29}{*}{ Mombasa } & \multirow{29}{*}{ 1997-1998 } & \multirow{2}{*}{ Sardinella gibbosa $\mathrm{n}$ muscle (fish) } & $\mathrm{Cd}$ & 4.8 & \multirow{29}{*}{ FAAS } & \multirow{29}{*}{ [284] } \\
\hline & & & & $\mathrm{Pb}$ & 3.4 & & \\
\hline & & & \multirow{2}{*}{ Leiognathus equula muscle (fish) } & $\mathrm{Cd}$ & 18.5 & & \\
\hline & & & & $\mathrm{Pb}$ & 0.76 & & \\
\hline & & & \multirow{2}{*}{ Upeneus spp muscle (fish) } & $\mathrm{Cd}$ & 6.0 & & \\
\hline & & & & $\mathrm{Pb}$ & 0.4 & & \\
\hline & & & \multirow{2}{*}{ Lutjanus fulviflamma muscle (fish) } & $\mathrm{Cd}$ & 2.0 & & \\
\hline & & & & $\mathrm{Pb}$ & 0.2 & & \\
\hline & & & \multirow{2}{*}{ Sphraena jello muscle (fish) } & $\mathrm{Cd}$ & 9.8 & & \\
\hline & & & & $\mathrm{Pb}$ & 0.09 & & \\
\hline & & & \multirow{2}{*}{ Monodactylus argenteus muscle (fish) } & $\mathrm{Cd}$ & 1.6 & & \\
\hline & & & & $\mathrm{Pb}$ & 0.2 & & \\
\hline & & & Secutor insidiator muscle (fish) & $\mathrm{Pb}$ & 0.2 & & \\
\hline & & & \multirow{2}{*}{ Mugil múgil muscle (fish) } & $\mathrm{Cd}$ & 5.0 & & \\
\hline & & & & $\mathrm{Pb}$ & 0.1 & & \\
\hline & & & \multirow{2}{*}{ Carangoides gymnostethus muscle (fish) } & $\mathrm{Cd}$ & 1.6 & & \\
\hline & & & & $\mathrm{Pb}$ & 0.2 & & \\
\hline & & & \multirow{2}{*}{ Geres oyena muscle (fish) } & $\mathrm{Cd}$ & 1.0 & & \\
\hline & & & & $\mathrm{Pb}$ & nd & & \\
\hline & & & \multirow{2}{*}{ Crenidens crenidens muscle (fish) } & $\mathrm{Cd}$ & 1.4 & & \\
\hline & & & & $\mathrm{Pb}$ & 0.2 & & \\
\hline & & & \multirow{2}{*}{ Chorinemus tol muscle (fish) } & $\mathrm{Cd}$ & 2.2 & & \\
\hline & & & & $\mathrm{Pb}$ & 0.4 & & \\
\hline & & & \multirow{2}{*}{ Leptoscarus vaigiensis muscle (fish) } & $\mathrm{Cd}$ & 5.8 & & \\
\hline & & & & $\mathrm{Pb}$ & 0.2 & & \\
\hline & & & \multirow{2}{*}{ Spilotichthys pictus muscle (fish) } & $\mathrm{Cd}$ & 4.8 & & \\
\hline & & & & $\mathrm{Pb}$ & 0.15 & & \\
\hline & & & \multirow{2}{*}{ Siganus sutor muscle (fish) } & $\mathrm{Cd}$ & 6.0 & & \\
\hline & & & & $\mathrm{Pb}$ & 0.2 & & \\
\hline
\end{tabular}


Table 4. Cont.

\begin{tabular}{|c|c|c|c|c|c|c|c|}
\hline Country & Local & Date & Seafood & Heavy Metal & Concentration, $\mathrm{mgKg}^{-1}$ & Detection & \multirow[t]{2}{*}{ Reference } \\
\hline & & & \multirow{2}{*}{ Lenthrinus sp. muscle (fish) } & $\mathrm{Cd}$ & 1.0 & & \\
\hline & & & & $\mathrm{Pb}$ & 0.2 & & \\
\hline & & & \multirow{2}{*}{ Therapon jarbu muscle (fish) } & $\mathrm{Cd}$ & 0.6 & & \\
\hline & & & & $\mathrm{Pb}$ & 0.04 & & \\
\hline \multirow{18}{*}{ Tanzania } & \multirow{6}{*}{ Dar es Salaam } & \multirow{6}{*}{2015} & \multirow{2}{*}{ Siganus sutor muscle (fish) } & $\mathrm{Cd}$ & 0.04 & \multirow{6}{*}{ HR-ICP-MS } & \multirow{6}{*}{ [295] } \\
\hline & & & & $\mathrm{Pb}$ & 0.045 & & \\
\hline & & & \multirow{2}{*}{ Lethrinus harak muscle (fish) } & $\mathrm{Cd}$ & 0.14 & & \\
\hline & & & & $\mathrm{Pb}$ & 0.144 & & \\
\hline & & & \multirow{2}{*}{$\begin{array}{l}\text { Rastrelliger } \\
\text { Kanagurta muscle (fish) }\end{array}$} & $\mathrm{Cd}$ & 0.13 & & \\
\hline & & & & $\mathrm{Pb}$ & 0.067 & & \\
\hline & Dar es Salaam & \multirow{2}{*}{2013} & \multirow{2}{*}{ Octopus cyanea muscle (octopus) } & $\mathrm{Pb}$ & 7.22 & \multirow{2}{*}{ ICP-AES } & \multirow{2}{*}{ [286] } \\
\hline & Tanga & & & $\mathrm{Pb}$ & 3.24 & & \\
\hline & \multirow{3}{*}{ Dar es Salaam } & \multirow{3}{*}{$2007-2008$} & \multirow{3}{*}{$\begin{array}{l}\text { Saccostrea } \\
\text { Cucullate soft tissue (oyster) }\end{array}$} & $\mathrm{Cd}$ & 1.00 & \multirow{2}{*}{ ICP-OES } & \multirow{3}{*}{ [23] } \\
\hline & & & & $\mathrm{Pb}$ & 2.00 & & \\
\hline & & & & $\mathrm{Hg}$ & 0.081 & SAHgA & \\
\hline & \multirow{6}{*}{ Dar es Salaam } & \multirow{6}{*}{2016} & \multirow{2}{*}{ Rastrellieger kanagurta muscle (fish) } & $\mathrm{Pb}$ & 0.03 & \multirow{6}{*}{ FAAS } & \multirow{6}{*}{ [2] } \\
\hline & & & & $\mathrm{Cd}$ & 0.06 & & \\
\hline & & & \multirow{2}{*}{ Lutjanus fulvus muscle (fish) } & $\mathrm{Pb}$ & 0.14 & & \\
\hline & & & & $\mathrm{Cd}$ & 0.16 & & \\
\hline & & & \multirow{2}{*}{ Fenneropenaeus indicus muscle (fish) } & $\mathrm{Pb}$ & 0.06 & & \\
\hline & & & & $\mathrm{Cd}$ & 0.01 & & \\
\hline & Zanzibar & 2011 & Anadara antiquata muscle (fish) & $\mathrm{Pb}$ & 3.5 & FAAS & [291] \\
\hline & & & & $\mathrm{Cd}$ & 0.60 & & \\
\hline & & & Xiphias gladius muscle (fish) & $\mathrm{Pb}$ & 0.01 & ICP-AES & \\
\hline & & & & $\mathrm{Hg}$ & 3.97 & AHgA & \\
\hline & & & & $\mathrm{Cd}$ & 0.26 & J & \\
\hline & & & Thunnus albacares muscle (fish) & $\mathrm{Pb}$ & 0.02 & ICP-AES & \\
\hline $\begin{array}{l}\text { Mozambique } \\
\text { Channel }\end{array}$ & East of Madagascar & 2004 & & $\mathrm{Hg}$ & 1.15 & AHgA & [292] \\
\hline & & & & $\mathrm{Cd}$ & 0.61 & & \\
\hline & & & Katsuwonus pelamis muscle (fish) & $\mathrm{Pb}$ & 0.07 & ICP-AES & \\
\hline & & & & $\mathrm{Hg}$ & 0.67 & AHgA & \\
\hline & & & & $\mathrm{Cd}$ & 0.13 & & \\
\hline & & & Coryphaena hippurus muscle (fish) & $\mathrm{Pb}$ & 0.06 & ICP-AES & \\
\hline
\end{tabular}


Table 4. Cont.

\begin{tabular}{|c|c|c|c|c|c|c|c|}
\hline & & & & $\mathrm{Hg}$ & 0.21 & $\mathrm{AHgA}$ & \\
\hline & \multirow{9}{*}{ Northern part } & & \multirow{3}{*}{ Xiphias gladius muscle (fish) } & $\mathrm{Cd}$ & 1.04 & \multirow{2}{*}{ ICP-AES } & \\
\hline & & & & $\mathrm{Pb}$ & 0.12 & & \\
\hline & & & & $\mathrm{Hg}$ & 1.61 & $\mathrm{AHgA}$ & \\
\hline & & & \multirow{3}{*}{ Thunnus albacares muscle (fish) } & $\mathrm{Cd}$ & 0.25 & \multirow{2}{*}{ ICP-AES } & \\
\hline & & & & $\mathrm{Pb}$ & 0.09 & & \\
\hline & & & & $\mathrm{Hg}$ & 0.56 & $\mathrm{AHgA}$ & \\
\hline & & & \multirow{3}{*}{ Coryphaena hippurus muscle (fish) } & $\mathrm{Cd}$ & 0.12 & \multirow{2}{*}{ ICP-AES } & \\
\hline & & & & $\mathrm{Pb}$ & 0.14 & & \\
\hline & & & & $\mathrm{Hg}$ & 0.98 & $\mathrm{AHgA}$ & \\
\hline \multirow{3}{*}{ South Africa } & \multirow{3}{*}{ Cape Town } & \multirow{3}{*}{2011} & \multirow{3}{*}{ Mytilus galloprovincialis (bivalve mollusk) } & $\mathrm{Cd}$ & 1.99 & \multirow{3}{*}{ ICP - MS } & \multirow{3}{*}{ [287] } \\
\hline & & & & $\mathrm{Pb}$ & 7.30 & & \\
\hline & & & & $\mathrm{Hg}$ & 4.93 & & \\
\hline
\end{tabular}

SAHgA—semi-automatic mercury analyzer, AHgA—Advanced Mercury Analyzer, ICP—Inductively Coupled Plasm, MS—Mass Spectroscopy, AES—Atomic Emission Spectrometry, HR-High Resolution, FAAS-Flame Atomic Absorption Spectrometry. 


\section{Final Considerations and Recommendations}

Among several marine organism species, shellfish have been reported to be more sensitive and can be used as marine bioindicators of HM pollution [296]. The habitat change assessment, a description of the natural characteristics of aquatic systems [296], the ability of bioaccumulation of HM and very low locomotion [297-299] and seafood in human diet [1,300], among other aspects, are indicated as advantages of using shellfishes as bioindicators of HM pollution in the marine environment. On the African Red Sea coast, several species of mollusks $[19,281,289]$ and fishes $[288,290]$ have presented Cd, $\mathrm{Pb}$ and $\mathrm{Hg}$ concentrations higher than permitted limit by FAOUN/EU regulations [206]. Moreover, on the Indian Ocean coast species of fishes and invertebrates were found with a higher content of $\mathrm{Pb}, \mathrm{Hg}$ and Cd [23,284,286,287,291,292]. These data indicate the need for serious monitoring programs and control of HM in seafood. Many studies of the incidence of heavy metals in the Indian Ocean and the Red Sea involve fishes species (Cyprinus carpio, Carassius auratus, Corydoras paleatus, Oreochromis mossambicus, Dicentrarchus labrax, Oreochromis niloticus, Oncorynchus mykiss, Anabas testudineus, Channa punctatus, Anguilla Anguilla, Sparus aurata, Leuciscus idus, Pimephales promelas, Clarias batrachus, Clarias gariepinus, Acipenser sinensis) [301-317]. These studies cannot give realistic information about HM pollution because fishes are migratory species, and consequently, are not suitable as HM bioindicators. The reported potential HM bioindicator species include invertebrate mollusks Barbatus barbatus and Patella caerulea [19]. There are currently no registered human poisoning cases related to $\mathrm{Cd}, \mathrm{Hg}$ and $\mathrm{Pb}$ in the African countries bordering the Indian Ocean and the Red Sea. The lack of such data may be partly related to the lack of trained health staff to recognize signs/symptoms of heavy metal poisoning in humans. The aquaculture system of most consumed fish and shellfish species is strongly recommended, because it can avoid or minimize the consumption of contaminated seafood.

Author Contributions: Conceptualization, I.J.T.; Introduction, I.J.T. and P.V.L.; Heavy Metal and their effects on humans, I.J.T; Heavy Metal poisoning treatment, I.J.T.; The incidence of cadmium, mercury and lead in seafood from in the African countries bordering the Indian Ocean and the Red Sea, I.J.T. and P.V.L. All authors have read and agreed to the published version of the manuscript.

Funding: This research has received external funding from Investigation National Fund-Mozambique.

Acknowledgments: The authors thank the Fundação Calouste Gulbenkian for the partial PhD scholarship attributed to the first author (I.J.T.).

Conflicts of Interest: The authors declare no conflict of interest.

\section{References}

1. Smith, M.D.; Roheim, C.A.; Crowder, L.B.; Halpern, B.S.; Turnipseed, M.; Anderson, J.L.; Asche, F.; Bourillón, L.; Guttormsen, A.G.; Khan, A. Sustainability and Global Seafood. Science 2010, 327, 784-786. [CrossRef] [PubMed]

2. Saria, J.A. Assessment of Health Risks Associated with Concentrations of Heavy Metals in Fish from the Coast of Tanzania. J Multidiscip. Eng. Sci. Stud. 2016, 2, 1147-1153.

3. Zalloua, P.; Hsu, Y.-H.; Terwedow, H.; Zang, T.; Wu, D.; Tang, G.; Li, Z.; Hong, X.; Azar, S.; Wang, B.; et al. Impact of seafood and fruit consumption on bone mineral density. Maturitas 2007, 56, 1-11. [CrossRef] [PubMed]

4. Vogiatzoglou, A.; Smith, A.D.; Nurk, E.; Berstad, P.; A Drevon, C.; Ueland, P.M.; E Vollset, S.; Tell, G.S.; Refsum, H.; Smith, A. Dietary sources of vitamin B-12 and their association with plasma vitamin B-12 concentrations in the general population: The Hordaland Homocysteine Study. Am. J. Clin. Nutr. 2009, 89, 1078-1087. [CrossRef]

5. Ekweagwu, E.; Agwu, A.; Madukwe, E. The role of micronutrients in child health: A review of the literature. Afr. J. Biotechnol. 2008, 7, 3804-3810.

6. Weber, D.N.; Connaughton, V.; Dellinger, J.A.; Klemer, D.; Udvadia, A.; Carvan, M.J. Selenomethionine reduces visual deficits due to developmental methylmercury exposures. Physiol. Behav. 2008, 93, $250-260$. [CrossRef] 
7. Heaney, R.P. Long-latency deficiency disease: Insights from calcium and vitamin D. Am. J. Clin. Nutr. 2003, 78, 912-919. [CrossRef]

8. Toyokuni, S. Role of iron in carcinogenesis: Cancer as a ferrotoxic disease. Cancer Sci. 2009, 100, 9-16. [CrossRef]

9. Millward, D.J.; Layman, D.; Tomé, D.; Schaafsma, G. Protein quality assessment: Impact of expanding understanding of protein and amino acid needs for optimal health. Am. J. Clin. Nutr. 2008, 87, 1576S-1581S. [CrossRef]

10. Ruxton, C.H.S.; Calder, P.C.; Reed, S.C.; Simpson, M.J.A. The impact of long-chainn-3 polyunsaturated fatty acids on human health. Nutr. Res. Rev. 2005, 18, 113-129. [CrossRef]

11. Fatoki, O.; Mathabatha, S. An assessment of heavy metal pollution in the East London and Port Elizabeth harbours. Water SA 2004, 27, 233-240. [CrossRef]

12. Hervé, R.P.; Andriamalala, R.; Yves, M.; Marcellin, R.; Christine, R.; Andriamandimbisoa, N. Assessment of heavy metals concentrations in coastal sediments in north-western cities of Madagascar. Afr. J. Environ. Sci. Technol. 2010, 4.

13. El Nemr, A.; El-Said, G.F.; Khaled, A.; Ragab, S. Distribution and ecological risk assessment of some heavy metals in coastal surface sediments along the Red Sea, Egypt. Int. J. Sediment Res. 2016, 31, 164-172. [CrossRef]

14. Madkour, H.A. Distribution and relationships of heavy metals in the giant clam (Tridacna maxima) and associated sediments from different sites in the Egyptian Red Sea coast. Egypt. J. Aquatic Res. 2005, 31, 45-59.

15. Mamboya, F.A. Heavy Metal Contamination and Toxicity: Studies of Macroalgae from the Tanzanian Coast. Ph.D. Thesis, Botaniska Institutionen, Stockholm University, Stockholm, Sweden, December 2007.

16. Usman, A.R.A.; Alkredaa, R.S.; Al-Wabel, M. Heavy metal contamination in sediments and mangroves from the coast of Red Sea: Avicennia marina as potential metal bioaccumulator. Ecotoxicol. Environ. Saf. 2013, 97, 263-270. [CrossRef]

17. Dœlsch, E.; Van De Kerchove, V.; Macary, H.S.; Doelsch, E. Heavy metal content in soils of Réunion (Indian Ocean). Geoderma 2006, 134, 119-134. [CrossRef]

18. Kamau, J.N. Heavy metal distribution and enrichment at Port-Reitz Creek, Mombasa. West. Indian Ocean J. Mar. Sci. 2002, 1, 65-70.

19. Hamed, M.A.; Emara, A.M. Marine molluscs as biomonitors for heavy metal levels in the Gulf of Suez, Red Sea. J. Mar. Syst. 2006, 60, 220-234. [CrossRef]

20. Biney, C.; Amuzu, A.; Calamari, D.; Kaba, N.; Mbome, I.; Naeve, H.; Ochumba, P.; Osibanjo, O.; Radegonde, V.; Saad, M. Review of Heavy Metals in the African Aquatic Environment. Ecotoxicol. Environ. Saf. 1994, 28, 134-159. [CrossRef]

21. Dœlsch, E.; Macary, H.S.; Van De Kerchove, V.; Doelsch, E. Sources of very high heavy metal content in soils of volcanic island (La Réunion). J. Geochem. Explor. 2006, 88, 194-197. [CrossRef]

22. Abu-Hilal, A.H.; Badran, M.M. Effect of pollution sources on metal concentration in sediment cores from the Gulf of Aqaba (red sea). Mar. Pollut. Bull. 1990, 21, 190-197. [CrossRef]

23. Machiwa, J. Coastal Marine Pollution in Dar es Salaam (Tanzania) relative to Recommended Environmental Quality Targets for the Western Indian Ocean. West. Indian Ocean J. Mar. Sci. 2010, 9, 17-30.

24. Mohammed, S.M. A Review of Water Quality and Pollution Studies in Tanzania. Ambio 2002, $31,617$. [CrossRef]

25. Ramessur, R.T. Anthropogenic-driven changes with focus on the coastal zone of Mauritius, south-western Indian Ocean. Reg. Environ. Chang. 2002, 3, 99-106. [CrossRef]

26. Martin, S.; Griswold, W. Human health effects of heavy metals. Environ. Sci. Technol. Briefs Citiz. 2009, 15, 1-6.

27. Morais, S.; E Costa, F.G.; de Lourdes Pereira, M. Heavy metals and human health. In Environmental Health-Emerging Issues and Practice; IntechOpen: London, UK, 2012.

28. Kirschvink, N.; Martin, N.; Fievez, L.; Smith, N.; Marlin, D.; Gustin, P. Airway inflammation in cadmium-exposed rats is associated with pulmonary oxidative stress and emphysema. Free. Radic. Res. 2006, 40, 241-250. [CrossRef] [PubMed]

29. Rana, S.V.S.; Boora, P. Antiperoxidative mechanisms offered by selenium against liver injury caused by cadmium and mercury in rat. Bull. Environ. Contam. Toxicol. 1992, 48, 120-124. [CrossRef] 
30. De Vizcaya-Ruiz, A.; Barbier, O.; Ruiz-Ramos, R.; Cebrián, M.E. Biomarkers of oxidative stress and damage in human populations exposed to arsenic. Mutat. Res. Toxicol. Environ. Mutagen. 2009, 674, 85-92. [CrossRef]

31. Wardman, P. Fluorescent and luminescent probes for measurement of oxidative and nitrosative species in cells and tissues: Progress, pitfalls, and prospects. Free Radic. Boil. Med. 2007, 43, 995-1022. [CrossRef]

32. Lee, D.-H.; Lim, J.-S.; Song, K.; Boo, Y.C.; Jacobs, D.R. Graded Associations of Blood Lead and Urinary Cadmium Concentrations with Oxidative-Stress-Related Markers in the U.S. Population: Results from the Third National Health and Nutrition Examination Survey. Environ. Heal. Perspect. 2006, 114, 350-354. [CrossRef]

33. Carneiro, M.F.H.; Grotto, D.; Barbosa, F. Inorganic and Methylmercury Levels in Plasma are Differentially Associated with Age, Gender, and Oxidative Stress Markers in a Population Exposed to Mercury Through Fish Consumption. J. Toxicol. Environ. Heal. Part A 2014, 77, 69-79. [CrossRef] [PubMed]

34. Shaikh, Z.A.; Vu, T.T.; Zaman, K. Oxidative Stress as a Mechanism of Chronic Cadmium-Induced Hepatotoxicity and Renal Toxicity and Protection by Antioxidants. Toxicol. Appl. Pharmacol. 1999, 154, 256-263. [CrossRef] [PubMed]

35. Lund, B.-O.; Miller, D.M.; Woods, J.S. Studies on $\mathrm{Hg}(\mathrm{II})$-induced $\mathrm{H} 2 \mathrm{O} 2$ formation and oxidative stress in vivo and in vitro in rat kidney mitochondria. Biochem. Pharmacol. 1993, 45, 2017-2024. [CrossRef]

36. Yoshioka, N.; Nakashima, H.; Hosoda, K.; Eitaki, Y.; Shimada, N.; Omae, K. Urinary Excretion of an Oxidative Stress Marker, 8-hydroxyguanine (8-OH-Gua), among Nickel-cadmium Battery Workers. J. Occup. Heal. 2008, 50, 229-235. [CrossRef] [PubMed]

37. Goering, P.L.; Klaassen, C.D. Zinc-induced tolerance to cadmium hepatotoxicity. Toxicol. Appl. Pharmacol. 1984, 74, 299-307. [CrossRef]

38. Liu, Y.; Liu, J.; Iszard, M.; Andrews, G.; Palmiter, R.; Klaassen, C. Transgenic Mice That Overexpress Metallothionein-I Are Protected from Cadmium Lethality and Hepatotoxicity. Toxicol. Appl. Pharmacol. 1995, 135, 222-228. [CrossRef]

39. Singhal, R.K.; Anderson, M.E.; Meister, A. Glutathione, a first line of defense against cadmium toxicity. FASEB J. 1987, 1, 220-223. [CrossRef]

40. Bagchi, D.; Bagchi, M.; Hassoun, E.A.; Stohs, S.J. Cadmium-induced excretion of urinary lipid metabolites, DNA damage, glutathione depletion, and hepatic lipid peroxidation in sprague-dawley rats. Boil. Trace Element Res. 1996, 52, 143-154. [CrossRef]

41. Goering, P.L. Lead-protein interactions as a basis for lead toxicity. NeuroToxicology 1993, 14, 45-60.

42. Castro-González, M.; Méndez-Armenta, M. Heavy metals: Implications associated to fish consumption. Environ. Toxicol. Pharmacol. 2008, 26, 263-271. [CrossRef]

43. Rahman, M.S.; Molla, A.H.; Saha, N.; Rahman, A. Study on heavy metals levels and its risk assessment in some edible fishes from Bangshi River, Savar, Dhaka, Bangladesh. Food Chem. 2012, 134, 1847-1854. [CrossRef] [PubMed]

44. Jaishankar, M.; Tseten, T.; Anbalagan, N.; Mathew, B.B.; Beeregowda, K.N. Toxicity, mechanism and health effects of some heavy metals. Interdiscip. Toxicol. 2014, 7, 60-72. [CrossRef] [PubMed]

45. Hutton, M.L.; Hutchinson, T.C. Lead, Mercury, Cadmium and Arsenic in the Environment; Hutchinson, T.C., Meema, K.M., Eds.; John Wiley \& Sons Ltd.: Hoboken, NJ, USA, 1987.

46. Hutton, M. Sources of cadmium in the environment. Ecotoxicol. Environ. Saf. 1983, 7, 9-24. [CrossRef]

47. Fielder, R.; Dale, E. Cadmium and Its Compounds; HM Stationery Office: Richmond, UK, 1983; Volume 7.

48. Thornton, I. Sources and pathways of cadmium in the environment. IARC Sci. Publ. 1992, 149-162.

49. Bernard, A.; Lauwerys, R. Cadmium in human population. Cell. Mol. Life Sci. 1984, 40, 143-152. [CrossRef]

50. Ros, J.; Slooff, W. Integrated Criteria Document. Cadmium; Technical Report; Rijksinstituut voor Volksgezondheid: Bilthoven, The Netherlands, December 2012.

51. WHO, C. Environmental Health Criteria; World Health Organization: Geneva, Switzerland, 1992.

52. Yu, M.-H. Environmental Toxicology. Environ. Toxicol. 2004.

53. Goldberg, E.D. Baseline Studies of Pollutants in the Marine Environment and Research Recommendations; National Science Foundation: Alexandria, VA, USA, 1972.

54. Soliman, Z.I. A study of heavy metals pollution in some aquatic organisms in Suez Canal in Port-Said Harbour. J. Appl. Sci. Res. 2006, 2, 657-663.

55. Ray, S. Bioaccumulation of cadmium in marine organisms. Cell. Mol. Life Sci. 1984, 40, 14-23. [CrossRef] 
56. Ray, S.; McLeese, D. Factors affecting uptake of cadmium and other trace metals from marine sediments by some bottom-dwelling marine invertebrates. Dredged-Mater. Dispos. Ocean. Ocean 1983, 2.

57. Nordberg, M. Studies on metallothionein and cadmium. Environ. Res. 1978, 15, 381-404. [CrossRef]

58. Prozialeck, W.C.; Edwards, J.; Woods, J.M. The vascular endothelium as a target of cadmium toxicity. Life Sci. 2006, 79, 1493-1506. [CrossRef] [PubMed]

59. Akesson, A.; Lundh, T.; Vahter, M.; Bjellerup, P.; Lidfeldt, J.; Nerbrand, C. Tubular and glomerular kidney effects in Swedish women with low environmental cadmium exposure. Environ. Health Perspect. 2005, 113, 1627-1631. [CrossRef] [PubMed]

60. Satarug, S.; Nishijo, M.; Ujjin, P.; Vanavanitkun, Y.; Moore, M.R. Cadmium-induced nephropathy in the development of high blood pressure. Toxicol. Lett. 2005, 157, 57-68. [CrossRef] [PubMed]

61. Jelovcan, S.; Gutschi, A.; Kleinhappl, B.; Sedlmayr, P.; Barth, S.; Marth, E. Effects of low concentrations of cadmium on immunoglobulin E production by human B lymphocytes in vitro. Toxicol. 2003, 188, 35-48. [CrossRef]

62. Hemdan, N.Y.A.; Emmrich, F.; Sack, U.; Wichmann, G.; Lehmann, J.; Adham, K.; Lehmann, I. The in vitro immune modulation by cadmium depends on the way of cell activation. Toxicol. 2006, 222, 37-45. [CrossRef]

63. Di Gioacchino, M.; Petrarca, C.; Perrone, A.; Farina, M.; Sabbioni, E.; Hartung, T.; Martino, S.; Esposito, D.L.; Lotti, L.V.; Mariani-Costantini, R. Autophagy as an ultrastructural marker of heavy metal toxicity in human cord blood hematopoietic stem cells. Sci. Total. Environ. 2008, 392, 50-58. [CrossRef]

64. Thompson, J.; Bannigan, J. Cadmium: Toxic effects on the reproductive system and the embryo. Reprod. Toxicol. 2008, 25, 304-315. [CrossRef]

65. Friberg, L.; Elinder, C.; Kjellstrom, T.; Nordberg, G.F. Cadmium and Health: A Toxicological and Epidemiological Appraisal Volume II: Effects and Response; CRC Press: Boca Raton, FL, USA, 1985; p. 320.

66. Johri, N.; Jacquillet, G.; Unwin, R. Heavy metal poisoning: The effects of cadmium on the kidney. BioMetals 2010, 23, 783-792. [CrossRef]

67. Nordberg, G. Historical perspectives on cadmium toxicology. Toxicol. Appl. Pharmacol. 2009, 238, $192-200$. [CrossRef]

68. Bernard, A.; Stolte, H.; De Broe, M.E.; Mueller, P.W.; Mason, H.; Lash, L.H.; Fowler, B.A. Urinary biomarkers to detect significant effects of environmental and occupational exposure to nephrotoxins. IV. Current information on interpreting the health implications of tests. Ren. Fail. 1997, 19, 553-566. [CrossRef]

69. Teeyakasem, W.; Nishijo, M.; Honda, R.; Satarug, S.; Swaddiwudhipong, W.; Ruangyuttikarn, W. Monitoring of cadmium toxicity in a Thai population with high-level environmental exposure. Toxicol. Lett. 2007, 169, 185-195. [CrossRef] [PubMed]

70. Nogawa, K.; Ishizaki, A.; Fukushima, M.; Shibata, I.; Hagino, N. Studies on the women with acquired fanconi syndrome observed in the Ichi River basin polluted by cadmium. Environ. Res. 1975, 10, 280-307. [CrossRef]

71. Bhattacharyya, M.H.; A Sacco-Gibson, N.; Peterson, D.P. Cadmium-induced bone loss: Increased susceptibility in female beagles after ovariectomy. IARC Sci. Publ. 1992, 279-286.

72. Goering, P.; Klaassen, C. Hepatotoxicology of copper, iron, and cadmium. Compr. Toxicol. 1997, 9, 389-406.

73. E Rikans, L.; Yamano, T. Mechanisms of cadmium-mediated acute hepatotoxicity. J. Biochem. Mol. Toxicol. 2000, 14, 110-117. [CrossRef]

74. Chou, I.N. Distinct cytoskeletal injuries induced by As, Cd, Co, Cr, and Ni compounds. Biomed. Environ. Sci. 1989, 2, 358-365. [PubMed]

75. Li, W.; Kagan, H.; Chou, I. Alterations in Cytoskeletal Organization and Homeostasis of Cellular Thiols in Cadmium-Resistant Cells. Toxicol. Appl. Pharmacol. 1994, 126, 114-123. [CrossRef]

76. Hussain, T.; Shukla, G.S.; Chandra, S.V. Effects of cadmium on superoxide dismutase and lipid peroxidation in liver and kidney of growing rats: In vivo and in vitro studies. Pharmacol. Toxicol. 1987, 60, 355-358. [CrossRef]

77. Stacey, N.H.; Cantilena, L.R.; Klaassen, C.D. Cadmium toxicity and lipid peroxidation in isolated rat hepatocytes. Toxicol. Appl. Pharmacol. 1980, 53, 470-480. [CrossRef]

78. Müller, L. Consequences of cadmium toxicity in rat hepatocytes: Mitochondrial dysfunction and lipid peroxidation. Toxicol. 1986, 40, 285-295. [CrossRef]

79. Strubelt, O. Comparative studies on the toxicity of mercury, cadmium, and copper toward the isolated perfused rat liver. J. Toxicol. Environ. Heal. Part A 1996, 47, 267-283. [CrossRef] [PubMed] 
80. Hassoun, E. Cadmium-induced production of superoxide anion and nitric oxide, DNA single strand breaks and lactate dehydrogenase leakage in J774A.1 cell cultures. Toxicology 1996, 112, 219-226. [CrossRef]

81. Habeebu, S.S.; Liu, J.; Klaassen, C.D. Cadmium-Induced Apoptosis in Mouse Liver. Toxicol. Appl. Pharmacol. 1998, 149, 203-209. [CrossRef] [PubMed]

82. Lemasters, J.J.V. Necrapoptosis and the mitochondrial permeability transition: Shared pathways to necrosis and apoptosis. Am. J. Physiol. Content 1999, 276, G1-G6. [CrossRef] [PubMed]

83. Dudley, R.E.; Gammal, L.M.; Klaassen, C.D. Cadmium-induced hepatic and renal injury in chronically exposed rats: Likely role of hepatic cadmium-metallothionein in nephrotoxicity. Toxicol. Appl. Pharmacol. 1985, 77, 414-426. [CrossRef]

84. Friberg, L. Cadmium and the kidney. Environ. Health Perspect. 1984, 54, 1-11. [CrossRef]

85. Shaikh, Z.A.; Smith, J. The mechanisms of hepatic and renal metallothionein biosynthesis in cadmium-exposed rats. Chem. Interact. 1977, 19, 161-171. [CrossRef]

86. Shaikh, Z.A.; Smith, J. The biosynthesis of metallothionein in rat liver and kidney after administration of cadmium. Chem. Interactions 1976, 15, 327-336. [CrossRef]

87. Shaikh, Z.A.; Lucis, O.J. Cadmium and Zinc Binding in Mammalian Liver and Kidneys. Arch. Environ. Heal. Int. J. 1972, 24, 419-425. [CrossRef]

88. Webb, M. Role of Metallothionein in Cadmium Metabolism; Springer Science and Business Media LLC.: Berlin/Heidelberg, Germany, 1986; Volume 80, pp. 281-337.

89. Chan, H.-M.; Zhu, L.; Zhong, R.; Grant, D.; Goyer, R.; Cherian, M. Nephrotoxicity in Rats Following Liver Transplantation from Cadmium-Exposed Rats. Toxicol. Appl. Pharmacol. 1993, 123, 89-96. [CrossRef]

90. Cherian, M.G.; Shaikh, Z.A. Metabolism of intravenously injected cadmium-binding protein. Biochem. Biophys. Res. Commun. 1975, 65, 863-869. [CrossRef]

91. Foulkes, E. Renal tubular transport of cadmium-metallothionein. Toxicol. Appl. Pharmacol. 1978, 45, 505-512. [CrossRef]

92. Squibb, K.S.; Ridlington, J.W.; Carmichael, N.G.; Fowler, B.A. Early cellular effects of circulating cadmium-thionein on kidney proximal tubules. Environ. Health Perspect. 1979, 28, 287-296. [CrossRef] [PubMed]

93. Nomiyama, K.; Nomiyama, H. Critical concentration of 'unbound' cadmium in the rabbit renal cortex. Cell. Mol. Life Sci. 1986, 42, 149. [CrossRef] [PubMed]

94. Squibb, K.S.; Pritchard, J.B.; A Fowler, B. Cadmium-Metallothionein nephropathy: Relationships between ultrastructural/biochemical alterations and intracellular cadmium binding. J. Pharmacol. Exp. Ther. 1984, 229, 311-321. [PubMed]

95. Goyer, R.A.; Miller, C.R.; Zhu, S.-Y.; Victery, W. Non-metallothionein-bound cadmium in the pathogenesis of cadmium nephrotoxicity in the rat. Toxicol. Appl. Pharmacol. 1989, 101, 232-244. [CrossRef]

96. International Agency for Research on Can. IARC Monographs on the Evaluation of the Carcinogenic Risks to Humans: Beryllium, Cadmium, Mercury, and Exposures in the Glass Manufacturing Industry; World Health Organization: Geneva, Switzerland, 1993; Volume 58.

97. Program, N.T. Ninth Report on Carcinogens; National Toxicology Program: Research Triangle Park, NC, USA, 2000.

98. Achanzar, W.E.; Achanzar, K.B.; Lewis, J.G.; Webber, M.M.; Waalkes, M.P. Cadmium Induces c-myc, p53, and c-jun Expression in Normal Human Prostate Epithelial Cells as a Prelude to Apoptosis. Toxicol. Appl. Pharmacol. 2000, 164, 291-300. [CrossRef]

99. Polla, B.S.; Stubbe, H.; Maridonneau-Parini, I.; Jacquier-Sarlin, M. Differential induction of stress proteins and functional effects of heat shock in human phagocytes. Inflammation 1995, 19, 363-378. [CrossRef]

100. Somji, S.; Todd, J.H.; Sens, M.A.; Garrett, S.H.; Sens, D.A. Expression of the constitutive and inducible forms of heat shock protein 70 in human proximal tubule cells exposed to heat, sodium arsenite, and $\mathrm{CdCl}(2)$. Environ. Health Perspect. 1999, 107, 887-893.

101. Garcia-Morales, P.; Saceda, M.; Kenney, N.; Kim, N.; Salomon, D.S.; Gottardis, M.M.; Solomon, H.B.; Sholler, P.F.; Jordan, V.C.; Martin, M.B. Effect of cadmium on estrogen receptor levels and estrogen-induced responses in human breast cancer cells. J. Boil. Chem. 1994, 269, 16896-16901.

102. Hatcher, E.L.; Chen, Y.; Kang, Y. Cadmium resistance in A549 cells correlates with elevated glutathione content but not antioxidant enzymatic activities. Free Radic. Boil. Med. 1995, 19, 805-812. [CrossRef] 
103. Schwartz, G.G.; Reis, I.M. Is cadmium a cause of human pancreatic cancer? Cancer Epidemiol. Biomarkers Prev. 2000, 9, 139-145.

104. Pesch, B.; Haerting, J.; Ranft, U.; Klimpel, A.; Oelschlägel, B.; Schill, W. Occupational risk factors for urothelial carcinoma: Agent-specific results from a case-control study in Germany. Int. J. Epidemiol. 2000, 29, 238-247. [CrossRef] [PubMed]

105. Hu, J.; Mao, Y.; White, K. The Canadian Cancer Registries Epidemiology Research Group Renal cell carcinoma and occupational exposure to chemicals in Canada. Occup. Med. 2002, 52, 157-164. [CrossRef] [PubMed]

106. Keeler, G.; Glinsorn, G.; Pirrone, N. Particulate mercury in the atmosphere: Its significance, transport, transformation and sources. Water Air Soil Pollut. 1995, 80, 159-168. [CrossRef]

107. Mason, R.P. Mercury emissions from natural processes and their importance in the global mercury cycle. In Mercury Fate and Transport in the Global Atmosphere; Springer Science and Business Media LLC.: Berlin/Heidelberg, Germany, 2009; pp. 173-191.

108. Pirrone, N.; Costa, P.; Pacyna, J.; Ferrara, R. Mercury emissions to the atmosphere from natural and anthropogenic sources in the Mediterranean region. Atmos. Environ. 2001, 35, 2997-3006. [CrossRef]

109. Pacyna, E.G.; Pacyna, J.M.; Steenhuisen, F.; Wilson, S. Global anthropogenic mercury emission inventory for 2000. Atmos. Environ. 2006, 40,4048-4063. [CrossRef]

110. Pirrone, N.; Cinnirella, S.; Feng, X.; Finkelman, R.B.; Friedli, H.R.; Leaner, J.; Mason, R.P.; Mukherjee, A.B.; Stracher, G.B.; Streets, D.G.; et al. Global mercury emissions to the atmosphere from anthropogenic and natural sources. Atmos. Chem. Phys. Discuss. 2010, 10, 5951-5964. [CrossRef]

111. EFSA Panel on Contaminants in the Food Chain (CONTAM). Scientific Opinion on the risk for public health related to the presence of mercury and methylmercury in food. EFSA J. 2012, 10, 2985.

112. Kuban, P.; Houserová, P.; Kuban, P.; Hauser, P.C.; Kubáň, V. Mercury speciation by CE: A review. Electrophoresis 2007, 28, 58-68. [CrossRef]

113. Paquette, K.E.; Helz, G.R. Inorganic Speciation of Mercury in Sulfidic Waters: The Importance of Zero-Valent Sulfur. Environ. Sci. Technol. 1997, 31, 2148-2153. [CrossRef]

114. FAO/WHO (Food and Agriculture Organization of the United Nations/World Health. Safety evaluation of certain food additives and contaminants. Methylmercury. WHO Food Addit. Ser. 2011, 63, 605-684.

115. Bloom, N.S. On the Chemical Form of Mercury in Edible Fish and Marine Invertebrate Tissue. Can. J. Fish. Aquat. Sci. 1992, 49, 1010-1017. [CrossRef]

116. Silbernagel, S.M.; Carpenter, D.O.; Gilbert, S.G.; Gochfeld, M.; Groth, E.; Hightower, J.; Schiavone, F.M. Recognizing and Preventing Overexposure to Methylmercury from Fish and Seafood Consumption: Information for Physicians. J. Toxicol. 2011, 2011, 1-7. [CrossRef] [PubMed]

117. Harris, H.H. The Chemical Form of Mercury in Fish. Science 2003, 301, 1203. [CrossRef] [PubMed]

118. Ratcliffe, H.E.; Swanson, G.M.; Fischer, L.J. Human exposure to mercury: A critical assessment of the evidence of adverse health effects. J. Toxicol. Environ. Health 1996, 49, 221-270. [CrossRef] [PubMed]

119. Franco, J.L.; Braga, H.; Stringari, J.; Missau, F.C.; Posser, T.; Mendes, B.G.; Leal, R.; Dos Santos, A.R.S.; Dafre, A.L.; Pizzolatti, M.G.; et al. Mercurial-Induced Hydrogen Peroxide Generation in Mouse Brain Mitochondria: Protective Effects of Quercetin. Chem. Res. Toxicol. 2007, 20, 1919-1926. [CrossRef]

120. Baraldi, M.; Zanoli, P.; Tascedda, F.; Blom, J.M.C.; Brunello, N. Cognitive deficits and changes in gene expression of NMDA receptors after prenatal methylmercury exposure. Environ. Heal. Perspect. 2002, 110, 855-858. [CrossRef]

121. Harada, M. Minamata Disease: Methylmercury Poisoning in Japan Caused by Environmental Pollution. Crit. Rev. Toxicol. 1995, 25, 1-24. [CrossRef]

122. Castoldi, A.F.; Coccini, T.; Ceccatelli, S.; Manzo, L. Neurotoxicity and molecular effects of methylmercury. Brain Res. Bull. 2001, 55, 197-203. [CrossRef]

123. Bose-O'Reilly, S.; McCarty, K.M.; Steckling, N.; Lettmeier, B. Mercury exposure and children's health. Curr. Probl. Pediatric Adolesc. Health Care 2010, 40, 186-215. [CrossRef] [PubMed]

124. Zalups, R.K. Molecular interactions with mercury in the kidney. Pharmacol. Rev. 2000, 52, 113-144. [PubMed]

125. Ballatori, N. Transport of toxic metals by molecular mimicry. Environ. Heal. Perspect. 2002, 110, 689-694. [CrossRef] [PubMed]

126. Bando, I.; Reus, M.I.S.; Andrés, D.; Cascales, M. Endogenous antioxidant defence system in rat liver following mercury chloride oral intoxication. J. Biochem. Mol. Toxicol. 2005, 19, 154-161. [CrossRef] [PubMed] 
127. Rooney, J. The role of thiols, dithiols, nutritional factors and interacting ligands in the toxicology of mercury. Toxicology 2007, 234, 145-156. [CrossRef] [PubMed]

128. Papp, L.V.; Lu, J.; Holmgren, A.; Khanna, K.K. From Selenium to Selenoproteins: Synthesis, Identity, and Their Role in Human Health. Antioxidants Redox Signal. 2007, 9, 775-806. [CrossRef]

129. Carvalho, C.M.; Chew, E.-H.; Hashemy, S.I.; Lu, J.; Holmgren, A. Inhibition of the human thioredoxin system a molecular mechanism of mercury toxicity. J. Biol. Chem. 2008, 283, 11913-11923. [CrossRef]

130. Prati, M.; Gornati, R.; Boracchi, P.; Biganzoli, E.M.; Fortaner, S.; Pietra, R.; Sabbioni, E.; Bernardini, G. A comparative study of the toxicity of mercury dichloride and methylmercury, assayed by the Frog Embryo Teratogenesis Assay-Xenopus (FETAX). Altern. Lab. Anim. 2002, 30, 23-32. [CrossRef]

131. Counter, S.; Buchanan, L.H. Mercury exposure in children: A review. Toxicol. Appl. Pharmacol. 2004, 198, 209-230. [CrossRef]

132. Davidson, P.W.; Myers, G.J.; Weiss, B. Mercury exposure and child development outcomes. Pediatr. 2004, 113, 1023-1029.

133. Boffetta, P.; Merler, E.; Vainio, H. Carcinogenicity of mercury and mercury compounds. Scand. J. Work. Environ. Heal. 1993, 19, 1-7. [CrossRef] [PubMed]

134. Lopez, M.E.C.; Macêdo, G.L.; Pereira, S.I.; Arrifano, G.D.P.; Picanço-Diniz, D.L.; Nascimento, J.L.M.D.; Herculano, A. Mercury and human genotoxicity: Critical considerations and possible molecular mechanisms. Pharmacol. Res. 2009, 60, 212-220. [CrossRef] [PubMed]

135. Leonard, A.; Jacquet, P.; Lauwerys, R. Mutagenicity and teratogenicity of mercury compounds. Mutat. Res. Genet. Toxicol. 1983, 114, 1-18. [CrossRef]

136. E Ariza, M.; Holliday, J.; Williams, M.V. Mutagenic effect of mercury (II) in eukaryotic cells. Vivo 1994, 8, 559-563.

137. Tchounwou, P.B.; Ayensu, W.K.; Ninashvili, N.; Sutton, D. Review: Environmental exposure to mercury and its toxicopathologic implications for public health. Environ. Toxicol. 2003, 18, 149-175. [CrossRef] [PubMed]

138. Flegal, A.R. Lead in tropical marine systems: A review. Sci. Total. Environ. 1986, 58, 1-8. [CrossRef]

139. EFSA Panel on Contaminants in the Food Chain. Scientific Opinion on lead in food. EFSA J. 2010, 8, 1570. [CrossRef]

140. Tukker, A.; Buijst, H.; van Oers, L.; van der Voet, E. Risks to health and the environment related to the use of lead in products. In TNO Strategy, Technology and Policy; TNO: Delft, The Netherlands, 2001.

141. Lee, T.-H.; Jiang, S.-J. Speciation of lead compounds in fish by capillary electrophoresis-inductively coupled plasma mass spectrometry. J. Anal. At. Spectrom. 2005, 20, 1270. [CrossRef]

142. Chen, Y.; Huang, L.; Wu, W.; Ruan, Y.; Wu, Z.; Xue, Z.; Fu, F. Speciation analysis of lead in marine animals by using capillary electrophoresis couple online with inductively coupled plasma mass spectrometry. Electrophoresis 2013, 35, 1346-1352. [CrossRef]

143. Chang, L.-F.; Jiang, S.-J.; Sahayam, A. Speciation analysis of mercury and lead in fish samples using liquid chromatography-inductively coupled plasma mass spectrometry. J. Chromatogr. A 2007, 1176, 143-148. [CrossRef]

144. Sakai, T. Biomarkers of Lead Exposure. Ind. Heal. 2000, 38, 127-142. [CrossRef]

145. O'Flaherty, E.J. Physiologically based models for bone-seeking elements. V. Lead absorption and disposition in childhood. Toxicol. Appl. Pharmacol. 1995, 131, 297-308. [CrossRef]

146. Lerda, D. Study of sperm characteristics in persons occupationally exposed to lead. Am. J. Ind. Med. 1992, 22, 567-571. [CrossRef] [PubMed]

147. Braunstein, G.D.; Dahlgren, J.; Loriaux, D.L. Hypogonadism in chronically lead-poisoned men. Infertil. 1978, 1, 33-51.

148. Assennato, G.; Paci, C.; Baser, M.E.; Molinini, R.; Candela, R.G.; Altamura, B.M.; Giorgino, R. Sperm Count Suppression without Endocrine Dysfunction in Lead-Exposed Men. Arch. Environ. Heal. Int. J. 1987, 42, 124-127. [CrossRef] [PubMed]

149. Telisman, S.; Cvitković, P.; Jurasović, J.; Pizent, A.; Gavella, M.; Rocić, B. Semen quality and reproductive endocrine function in relation to biomarkers of lead, cadmium, zinc, and copper in men. Environ. Health Perspect. 2000, 108, 45-53. [CrossRef] [PubMed]

150. Apostoli, P.; Kiss, P.; Porru, S.; Bonde, J.P.; Vanhoorne, M. Male reproductive toxicity of lead in animals and humans. ASCLEPIOS Study Group. Occup. Environ. Med. 1998, 55, 364-374. [CrossRef] 
151. Hogstedt, C.; Hane, M.; Agrell, A.; Bodin, L. Neuropsychological test results and symptoms among workers with well-defined long-term exposure to lead. Occup. Environ. Med. 1983, 40, 99-105. [CrossRef]

152. Mantere, P.; Hänninen, H.; Hernberg, S.; Luukkonen, R. A prospective follow-up study on psychological effects in workers exposed to low levels of lead. Scand. J. Work. Environ. Heal. 1984, 10, 43-50. [CrossRef]

153. Campara, P.; D'Andrea, F.; Micciolo, R.; Savonitto, C.; Tansella, M.; Zimmermann-Tansella, C. Psychological performance of workers with blood-lead concentration below the current threshold limit value. Int. Arch. Occup. Environ. Heal. 1984, 53, 233-246. [CrossRef]

154. Lead, W.I. Environmental Health Criteria 165: International Programme on Chemical Safety; World Health Organization: Geneva, Switzerland, 1995.

155. Loghman-Adham, M. Renal effects of environmental and occupational lead exposure. Environ. Health Perspect. 1997, 105, 928-939. [CrossRef]

156. Ehrlich, R.; Robins, T.; Jordaan, E.; Miller, S.; Mbuli, S.; Selby, P.; Wynchank, S.; Cantrell, A.; De Broe, M.; D'Haese, P.; et al. Lead absorption and renal dysfunction in a South African battery factory. Occup. Environ. Med. 1998, 55, 453-460. [CrossRef] [PubMed]

157. Goyer, R. Mechanisms of lead and cadmium nephrotoxicity. Toxicol. Lett. 1989, 46, 153-162. [CrossRef]

158. Gerhardsson, L.; Chettle, D.R.; Englyst, V.; Nordberg, G.F.; Nyhlin, H.; Scott, M.C.; Todd, A.C.; Vesterberg, O. Kidney effects in long term exposed lead smelter workers. Occup. Environ. Med. 1992, 49, 186-192. [CrossRef] [PubMed]

159. Coscia, G.C.; Discalzi, G.; Ponzetti, C. Immunological aspects of occupational lead exposure. La Med. del Lav. $1987,78,360$.

160. Ewers, U.; Stiller-Winkler, R.; Idel, H. Serum immunoglobulin, complement C3, and salivary IgA levels in lead workers. Environ. Res. 1982, 29, 351-357. [CrossRef]

161. Gidlow, D. Lead toxicity. Occup. Med. 2015, 65, 770. [CrossRef]

162. Markowitz, M. Lead Poisoning. Pediatr. Rev. 2000, 21, 327-335. [CrossRef]

163. Philip, A.T.; Gerson, B. Lead Poisoning-Part I: Incidence, Etiology, and Toxicokinetics. Clin. Lab. Med. 1994, 14, 423-444. [CrossRef]

164. Rabinowitz, M.B. Toxicokinetics of bone lead. Environ. Health Perspect. 1991, 91, 33-37. [CrossRef]

165. Skerfving, S.; Nilsson, U.; Schütz, A.; Gerhardsson, L. Biological monitoring of inorganic lead. Scand. J. Work. Environ. Heal. 1993, 19, 59-64.

166. Roberts, J.R.; Reigart, J.R.; Ebeling, M.; Hulsey, T.C.; Roberts, J. Time Required for Blood Lead Levels to Decline in Nonchelated Children. J. Toxicol. Clin. Toxicol. 2001, 39, 153-160. [CrossRef] [PubMed]

167. Rabinowitz, M.B.; Wetherill, G.W.; Kopple, J.D. Kinetic analysis of lead metabolism in healthy humans. J. Clin. Investig. 1976, 58, 260-270. [CrossRef] [PubMed]

168. Papanikolaou, N.C.; Hatzidaki, E.G.; Belivanis, S.; Tzanakakis, G.N.; Tsatsakis, A.M. Lead toxicity update. A brief review. Med Sci. Monit. 2005, 11, 329.

169. Philip, A.T.; Gerson, B. Lead Poisoning-Part II: Effects and Assay. Clin. Lab. Med. 1994, 14, 651-670. [CrossRef]

170. Seppäläinen, A.M. Electrophysiological evaluation of central and peripheral neural effects of lead exposure. NeuroToxicology 1984, 5, 43-52. [PubMed]

171. Needleman, H.L.; Gunnoe, C.; Leviton, A.; Reed, R.; Peresie, H.; Maher, C.; Barrett, P. Deficits in Psychologic and Classroom Performance of Children with Elevated Dentine Lead Levels. N. Engl. J. Med. 1979, 300, 689-695. [CrossRef]

172. Lidsky, T.I.; Schneider, J.S. Lead neurotoxicity in children: Basic mechanisms and clinical correlates. Brain 2003, 126, 5-19. [CrossRef]

173. A Otto, D.; A Fox, D. Auditory and visual dysfunction following lead exposure. NeuroToxicology 1993, 14, 191-207.

174. Holdstein, Y.; Pratt, H.; Goldsher, M.; Rosen, G.; Shenhav, R.; Linn, S.; Mor, A.; Barkai, A. Auditory brainstem evoked potentials in asymptomatic lead-exposed subjects. J. Laryngol. Otol. 1986, 100, 1031-1036. [CrossRef]

175. Cullen, M.R.; Robins, J.M.; Eskenazi, B. Adult inorganic lead intoxication: Presentation of 31 new cases and a review of recent advances in the literature. Medicine 1983, 62, 221-247. [CrossRef] [PubMed]

176. Needleman, H.L.; Schell, A.; Bellinger, D.; Leviton, A.; Allred, E.N. The Long-Term Effects of Exposure to Low Doses of Lead in Childhood. N. Engl. J. Med. 1990, 322, 83-88. [CrossRef] [PubMed] 
177. White, R.; Diamond, R.; Proctor, S.; Morey, C.; Hu, H. Residual cognitive deficits 50 years after lead poisoning during childhood. Occup. Environ. Med. 1993, 50, 613-622. [CrossRef] [PubMed]

178. Feldman, R.G.; White, R. Lead Neurotoxicity and Disorders of Learning. J. Child Neurol. 1992, 7, $354-359$. [CrossRef] [PubMed]

179. National Research Council Measuring Lead Exposure in Infants, Children, and Other Sensitive Populations; The National Academies Press: Washington, DC, USA, 1993.

180. Needleman, H.L. Lead-associated intellectual deficit. N. Engl. J. Med. 1982, 306, 367.

181. Loghman-Adham, M. Aminoaciduria and glycosuria following severe childhood lead poisoning. Pediatr. Nephrol. 1998, 12, 218-221. [CrossRef]

182. Hu, H. A 50-year follow-up of childhood plumbism. Hypertension, renal function, and hemoglobin levels among survivors. Am. J. Dis. Child. 1991, 145, 681-687. [CrossRef]

183. A Abdullah, M. Lead poisoning among children in Saudi Arabia. J. Trop. Med. Hyg. 1984, 87, 67-70.

184. Ponka, P. Cell biology of heme. Am. J. Med. Sci. 1999, 318, 241-256. [CrossRef]

185. Alvares, A.P.; Fischbein, A.; Sassa, S.; Anderson, K.; Kappas, A. Lead intoxication: Effects on cytochrome P-450-mediated hepatic oxidations. Clin. Pharmacol. Ther. 1976, 19, 183-190. [CrossRef]

186. Goldman, L.S.; Genel, M.; Bezman, R.J.; Slanetz, P. American Medical Association for the Council on Scientific Affairs Diagnosis and Treatment of Attention-Deficit/Hyperactivity Disorder in Children and Adolescents. JAMA 1998, 279, 1100. [CrossRef] [PubMed]

187. IARC Working Group on the Evaluation of Carcinogenic Risks to Humans. Inorganic and organic lead compounds. IARC Monogr. Eval. Carcinog. Risks Hum. 2006, 87, 1.

188. Evis, M.J.; Kane, K.A.; Moore, M.R.; Parratt, J.R. The effects of chronic lead treatment and hypertension on the severity of cardiac arrhythmias induced by coronary artery occlusion or by noradrenaline in anaesthetised rats. Arch. Toxicol. 1987, 59, 336-340. [CrossRef] [PubMed]

189. Lai, B.; Murthy, R.C.; Anand, M.; Chandra, S.V.; Kumar, R.; Tripathi, O.; Srimal, R.C. Cardiotoxicity and Hypertension in Rats After Oral Lead Exposure. Drug Chem. Toxicol. 1991, 14, 305-318. [CrossRef] [PubMed]

190. Khalil-Manesh, F.; Gonick, H.C.; Cohen, A.H. Experimental Model of Lead Nephropathy. III. Continuous Low-level Lead Administration. Arch. Environ. Heal. Int. J. 1993, 48, 271-278. [CrossRef] [PubMed]

191. Dreisbach, R. Handbook of poisoning: Prevention, diagnosis and treatment Lang Medical Publications. Los Altos 1983, 401, 3.

192. Sheabar, F.Z.; Yannai, S. Extracorporeal Complexation and Haemodialysis for the Treatment of Cadmium Poisoning. I. Effects of Four Chelators on thein VitroElimination of Cadmium from Human Blood. Pharmacol. Toxicol. 1989, 64, 257-261. [CrossRef]

193. Jones, M.M.; Basinger, M.A.; Topping, R.J.; Gale, G.R.; Jones, S.G.; Holscher, M.A. Meso-2,3-dimercaptosuccinic acid and sodium N-benzyl-N-dithiocarboxy-D-glucamine as antagonists for cadmium intoxication. Arch. Toxicol. 1988, 62, 29-36. [CrossRef]

194. Gale, G.R.; Smith, A.B.; Walker, E.M. Diethyldithiocarbamate in treatment of acute cadmium poisoning. Ann. Clin. Lab. Sci. 1981, 11, 476-483.

195. Miller, A.L. Dimercaptosuccinic acid (DMSA), a non-toxic, water-soluble treatment for heavy metal toxicity. Altern. Med. Rev. A J. Clin. Ther. 1998, 3, 199-207.

196. Cotter, L.H. Treatment of cadmium poisoning with edathamil calcium disodium. J. Am. Med Assoc. 1958, 166, 735. [CrossRef] [PubMed]

197. Baum, C.R. Treatment of mercury intoxication. Curr. Opin. Pediatr. 1999, 11, 265-268. [CrossRef] [PubMed]

198. Toet, A.; Van Dijk, A.; Savelkoul, T.; Meulenbelt, J. Mercury Kinetics in a Case of Severe Mercuric Chloride Poisoning Treated with Dimercapto-1-propane Sulphonate (DMPS). Hum. Exp. Toxicol. 1994, 13, 11-16. [CrossRef] [PubMed]

199. Pfab, R.; Mückter, H.; Roider, G.; Zilker, T. Clinical Course of Severe Poisoning with Thiomersal. J. Toxicol. Clin. Toxicol. 1996, 34, 453-460. [CrossRef]

200. Longcope, W.T.; Luetscher, J.A.; Calkins, E.; Grob, D.; Bush, S.W.; Eisenberg, H. CLINICAL USES OF 2,3-DIMERCAPTOPROPANOL (BAL). XI. THE TREATMENT OF ACUTE MERCURY POISONING BY BAL 1. J. Clin. Investig. 1946, 25, 557-567. [CrossRef]

201. Berlin, C.M.; Gorman, R.L.; May, D.G.; Notterman, D.A.; Weismann, D.N.; Wilson, S.G.; Wilson, J.T.; Bennett, D.R.; Mulinare, J.; Kaufman, P.; et al. Treatment guidelines for lead exposure in children. Pediatrics $1995,96,155-160$. 
202. Garçon, G.; Leleu, B.; Marez, T.; Zerimech, F.; Haguenoer, J.-M.; Furon, D.; Shirali, P. Biomonitoring of the adverse effects induced by the chronic exposure to lead and cadmium on kidney function: Usefulness of alpha-glutathione S-transferase. Sci. Total. Environ. 2007, 377, 165-172. [CrossRef]

203. Uchida, M.; Teranishi, H.; Aoshima, K.; Katoh, T.; Kasuya, M.; Inadera, H. Elevated urinary levels of vitamin D-binding protein in the inhabitants of a cadmium polluted area, Jinzu River basin, Japan. Tohoku J. Exp. Med. 2007, 211, 269-274. [CrossRef]

204. Yamagami, T.; Suna, T.; Fukui, Y.; Ohashi, F.; Takada, S.; Sakurai, H.; Aoshima, K.; Ikeda, M. Biological variations in cadmium, $\alpha 1$-microglobulin, $\beta 2$-microglobulin and $\mathrm{N}$-acetyl- $\beta$-d-glucosaminidase in adult women in a non-polluted area. Int. Arch. Occup. Environ. Heal. 2007, 81, 263-271. [CrossRef]

205. Prozialeck, W.; Vaidya, V.; Liu, J.; Waalkes, M.; Edwards, J.; Lamar, P.; Bernard, A.; Dumont, X.; Bonventre, J. Kidney injury molecule-1 is an early biomarker of cadmium nephrotoxicity. Kidney Int. 2007, 72, 985-993. [CrossRef]

206. UN Food and Agriculture Organization. Legal Notice No 66/2003 Heavy Metals Regulation, in 66; FAO: Rome, Italy, 2003.

207. Commission, E. Commission Regulation (EC) No 1881/2006 of 19 December 2006 Setting maximum levels for certain contaminants in foodstuffs. Off. J. Eur. Union 2006, 364.

208. South African Department of Health (DOH). Foodstuffs, Cosmetics and Disinfectants Act, 1972 (Act. 54 of 1972); South African Department of Health (DOH): Pretoria, South Africa, 2004.

209. Djedjibegovic, J.; Larssen, T.; Skrbo, A.; Marjanovic, A.; Sober, M. Contents of cadmium, copper, mercury and lead in fish from the Neretva river (Bosnia and Herzegovina) determined by inductively coupled plasma mass spectrometry (ICP-MS). Food Chem. 2012, 131, 469-476. [CrossRef]

210. Miedico, O.; Iammarino, M.; Pompa, C.; Tarallo, M.; Chiaravalle, A.E. Assessment of lead, cadmium and mercury in seafood marketed in Puglia and Basilicata (Italy) by inductively coupled plasma mass spectrometry. Food Addit. Contam. Part B 2015, 8, 1-8. [CrossRef]

211. Schmitt, C.; Brumbaugh, W.G.; Linder, G.L.; Hinck, J.E. A Screening-Level Assessment of Lead, Cadmium, and Zinc in Fish and Crayfish from Northeastern Oklahoma, USA. Environ. Geochem. Heal. 2006, 28, 445-471. [CrossRef] [PubMed]

212. Dural, M.; Genc, E.; Yemenicioğlu, S.; Sangun, M.K. Accumulation of Some Heavy Metals Seasonally in Hysterotylacium aduncum (Nematoda) and Its Host Red Sea Bream, Pagellus erythrinus (Sparidae) from Gulf of Iskenderun (North-Eastern Mediterranean). Bull. Environ. Contam. Toxicol. 2009, 84, 125-131. [CrossRef] [PubMed]

213. Andrew, A.S.; Warren, A.J.; Barchowsky, A.; A Temple, K.; Klei, L.; Soucy, N.V.; A O’Hara, K.; Hamilton, J.W. Genomic and proteomic profiling of responses to toxic metals in human lung cells. Environ. Heal. Perspect. 2003, 111, 825-835. [CrossRef]

214. Shimoda, R.; Achanzar, W.E.; Qu, W.; Nagamine, T.; Takagi, H.; Mori, M.; Waalkes, M.P. Metallothionein Is a Potential Negative Regulator of Apoptosis. Toxicol. Sci. 2003, 73, 294-300. [CrossRef]

215. Voegborlo, R.; El-Methnani, A.; Abedin, M. Mercury, cadmium and lead content of canned tuna fish. Food Chem. 1999, 67, 341-345. [CrossRef]

216. Çelik, U.; Oehlenschläger, J. High contents of cadmium, lead, zinc and copper in popular fishery products sold in Turkish supermarkets. Food Control. 2007, 18, 258-261. [CrossRef]

217. Santos, L.F.P.; Trigueiro, I.N.S.; Lemos, V.A.; Furtunato, D.M.D.N.; Cardoso, R.D.C.V. Assessment of cadmium and lead in commercially important seafood from São Francisco do Conde, Bahia, Brazil. Food Control. 2013, 33, 193-199. [CrossRef]

218. Geier, D.A.; Geier, M.R. A Prospective Study of Mercury Toxicity Biomarkers in Autistic Spectrum Disorders*. J. Toxicol. Environ. Heal. Part A 2007, 70, 1723-1730. [CrossRef] [PubMed]

219. Sigel, A.; Sigel, H. Metal Ions in Biological Systems: Mercury and Its Effects on Environment and Biology; CRC Press: Boca Raton, FL, USA, 1997; Volume 34.

220. Piotrowski, J.; Trojanowska, B.; Wiśniewska-Knypl, J.; Bolanowska, W. Mercury binding in the kidney and liver of rats repeatedly exposed to mercuric chloride: Induction of metallothionein by mercury and cadmium. Toxicol. Appl. Pharmacol. 1974, 27, 11-19. [CrossRef]

221. Branco, V.; Caito, S.; Farina, M.; Da Rocha, J.T.; Aschner, M.; Carvalho, C.; Da Rocha, J.B.T. Biomarkers of mercury toxicity: Past, present, and future trends. J. Toxicol. Environ. Heal. Part B 2017, 20, 119-154. [CrossRef] [PubMed] 
222. Barbosa, A.C.; Boischio, A.A.; East, G.A.; Ferrari, I.; Gonçalves, A.; Silva, P.R.M.; Da Cruz, T.M.E. Mercury contamination in the Brazilian Amazon. Environmental and occupational aspects. Water Air Soil Pollut. 1995, 80, 109-121. [CrossRef]

223. Dickman, M.; Leung, K. Mercury and organochlorine exposure from fish consumption in Hong Kong. Chemosphere 1998, 37, 991-1015. [CrossRef]

224. Nakagawa, R.; Yumita, Y.; Hiromoto, M. Total mercury intake from fish and shellfish by Japanese people. Chemosphere 1997, 35, 2909-2913. [CrossRef]

225. Vieira, C.; Morais, S.; Ramos, S.; Delerue-Matos, C.; Oliveira, M.B.P.P. Mercury, cadmium, lead and arsenic levels in three pelagic fish species from the Atlantic Ocean: Intra- and inter-specific variability and human health risks for consumption. Food Chem. Toxicol. 2011, 49, 923-932. [CrossRef]

226. Burger, J.; Gochfeld, M. Heavy metals in commercial fish in New Jersey. Environ. Res. 2005, 99, 403-412. [CrossRef]

227. Hight, S.C.; Cheng, J. Determination of total mercury in seafood by cold vapor-atomic absorption spectroscopy (CVAAS) after microwave decomposition. Food Chem. 2005, 91, 557-570. [CrossRef]

228. Plessi, M.; Bertelli, D.; Monzani, A. Mercury and Selenium Content in Selected Seafood. J. Food Compos. Anal. 2001, 14, 461-467. [CrossRef]

229. Pastore, A.; Federici, G.; Bertini, E.; Piemonte, F. Analysis of glutathione: Implication in redox and detoxification. Clin. Chim. Acta 2003, 333, 19-39. [CrossRef]

230. Gerson, R.J.; Shaikh, Z.A. Uptake and binding of cadmium and mercury to metallothionein in rat hepatocyte primary cultures. Biochem. J. 1982, 208, 465-472. [CrossRef] [PubMed]

231. Batista, B.L.; Rodrigues, J.L.; De Souza, S.S.; Souza, V.C.O.; Barbosa, F.; Barbosa, F. Mercury speciation in seafood samples by LC-ICP-MS with a rapid ultrasound-assisted extraction procedure: Application to the determination of mercury in Brazilian seafood samples. Food Chem. 2011, 126, 2000-2004. [CrossRef] [PubMed]

232. Hight, S.C.; Cheng, J. Determination of methylmercury and estimation of total mercury in seafood using high performance liquid chromatography (HPLC) and inductively coupled plasma-mass spectrometry (ICP-MS): Method development and validation. Anal. Chim. Acta 2006, 567, 160-172. [CrossRef]

233. Liu, Q. Determination of mercury and methylmercury in seafood by ion chromatography using photo-induced chemical vapor generation atomic fluorescence spectrometric detection. Microchem. J. 2010, 95, 255-258. [CrossRef]

234. Zmozinski, A.V.; Carneado, S.; Ibáñez-Palomino, C.; Sahuquillo, À.; López-Sánchez, F.; Da Silva, M.M. Method development for the simultaneous determination of methylmercury and inorganic mercury in seafood. Food Control. 2014, 46, 351-359. [CrossRef]

235. Berglund, M.; Lind, B.; Björnberg, K.A.; Palm, B.; Einarsson, O.; Vahter, M. Inter-individual variations of human mercury exposure biomarkers: A cross-sectional assessment. Environ. Heal. 2005, 4, 20. [CrossRef]

236. Haut, M.; Morrow, L.A.; Pool, D.; Callahan, T.S.; Haut, J.S.; Franzen, M.D. Neurobehavioral Effects of Acute Exposure to Inorganic Mercury Vapor. Appl. Neuropsychol. 1999, 6, 193-200. [CrossRef]

237. Torres, D.P.; Martins-Teixeira, M.; Silva, E.; Queiroz, H. Method development for the control determination of mercury in seafood by solid-sampling thermal decomposition amalgamation atomic absorption spectrometry (TDA AAS). Food Addit. Contam. Part A 2012, 29, 625-632. [CrossRef]

238. Motts, J.A.; Shirley, D.L.; Silbergeld, E.K.; Nyland, J.F. Novel biomarkers of mercury-induced autoimmune dysfunction: A cross-sectional study in Amazonian Brazil. Environ. Res. 2014, 132, 12-18. [CrossRef]

239. Nevado, J.J.B.; Martín-Doimeadiós, R.C.R.; Bernardo, F.J.G.; Moreno, M.J. Determination of mercury species in fish reference materials by gas chromatography-atomic fluorescence detection after closed-vessel microwave-assisted extraction. J. Chromatogr. A 2005, 1093, 21-28. [CrossRef] [PubMed]

240. Gerbersmann, C.; Heisterkamp, M.; Adams, F.C.; Broekaert, J. Two methods for the speciation analysis of mercury in fish involving microwave-assisted digestion and gas chromatography-atomic emission spectrometry. Anal. Chim. Acta 1997, 350, 273-285. [CrossRef]

241. Pereiro, I.R.; Wasik, A.; Łobiński, R.; ?obi?ski, R. Determination of mercury species in fish reference materials by isothermal multicapillary gas chromatography with atomic emission detection after microwave-assisted solubilization and solvent extraction. J. Anal. At. Spectrom. 1998, 13, 743-747. [CrossRef] 
242. Ebdon, L.; Foulkes, M.E.; Le Roux, S.; Mu??oz-Olivas, R.; Muñoz-Olivas, R. Cold vapour atomic fluorescence spectrometry and gas chromatography-pyrolysis-atomic fluorescence spectrometry for routine determination of total and organometallic mercury in food samples. Analyst 2002, 127, 1108-1114. [CrossRef] [PubMed]

243. Grinberg, P.; Campos, R.C.; Mester, Z.; Sturgeon, R. Solid phase microextraction capillary gas chromatography combined with furnace atomization plasma emission spectrometry for speciation of mercury in fish tissues. Spectrochim. Acta Part B: At. Spectrosc. 2003, 58, 427-441. [CrossRef]

244. E Desilva, P. Determination of lead in plasma and studies on its relationship to lead in erythrocytes. Occup. Environ. Med. 1981, 38, 209-217. [CrossRef] [PubMed]

245. Sakai, T.; Morita, Y.; Araki, T. Determination of lead in plasma, whole blood, and urine by icp-ms and the relationships among the three exposure indices. J. Occup. Med. Tox. 2003, 51, 50-57.

246. Schütz, A.; Bergdahl, I.; Ekholm, A.; Skerfving, S. Measurement by ICP-MS of lead in plasma and whole blood of lead workers and controls. Occup. Environ. Med. 1996, 53, 736-740. [CrossRef]

247. Schramel, P.; Wendler, I.; Angerer, J. The determination of metals (antimony, bismuth, lead, cadmium, mercury, palladium, platinum, tellurium, thallium, tin and tungsten) in urine samples by inductively coupled plasma-mass spectrometry. Int. Arch. Occup. Environ. Heal. 1997, 69, 219-223. [CrossRef]

248. Osman, K.; Zejda, J.E.; Schütz, A.; Mielzynska, D.; Elinder, C.G.; Vahter, M. Exposure to lead and other metals in children from Katowice district, Poland. Int. Arch. Occup. Environ. Heal. 1998, 71, 180-186. [CrossRef]

249. Mauras, Y.; Premel-Cabic, A.; Berre, S.; Allain, P. Simulataneous determination of lead, bismuth and thallium in plasma and urine by inductively coupled plasma mass spectrometry. Clin. Chim. Acta 1993, 218, 201-205. [CrossRef]

250. Berlin, A.; Schaller, K.H. European standardized method for the determination of delta-aminolevulinic acid dehydratase activity in blood. Z. klin. Chem. Klin. Biochem. 1974, 12, 389-390. [PubMed]

251. Vergnano, C.; Cartasegna, C.; Ardoino, V. Meccanismi di inhibizione dell'ativita' $\delta$-aminolevulinico deidratasica eritrocitaria nell'intossicazione da piombo umana e sperimentale. Med. Lav. 1969, 60, 505-516. [PubMed]

252. Meredith, P.; Moore, M.; Goldberg, A. Effects of Aluminium, Lead and Zinc on $\delta$-Aminolaevulinic Acid Dehydratase. Enzym. 1977, 22, 22-27. [CrossRef]

253. Evans, N.; Games, D.; Jackson, A.; Matlin, S. Applications of high-pressure liquid chromatography and field desorption mass spectrometry in studies of natural porphyrins and chlorophyll derivatives. J. Chromatogr. A 1975, 115, 325-333. [CrossRef]

254. Sakai, T.; Niinuma, Y.; Yanagihara, S.; Ushio, K. Liquid-chromatographic separation and determination of coproporphyrins I and III in urine. Clin. Chem. 1983, 29, 350-353. [CrossRef]

255. Salmi, M.; Tenhunen, R. New method for liquid-chromatographic measurement of erythrocyte protoporphyrin and coproporphyrin. Clin. Chem. 1980, 26, 1832-1835. [CrossRef]

256. Morgano, M.; Rabonato, L.C.; Milani, R.F.; Miyagusku, L.; Quintaes, K.D. As, Cd, Cr, Pb and Hg in seafood species used for sashimi and evaluation of dietary exposure. Food Control. 2014, 36, 24-29. [CrossRef]

257. Piomelli, S. A micromethod for free erythrocyte porphyrins: The FEP test. J. Lab. Clin. Med. 1973, 81, 932-940.

258. Niinuma, Y.; Sakai, T.; Yanagihara, S.; Ushio, K. [A modified FEP (free erythrocyte protoporphyrin) test (author's transl)]. Sangyo Igaku 1981, 23, 254-259. [CrossRef]

259. A Lamola, A.; Joselow, O.; Yamane, T. Zinc Protoporphyrin (ZPP): A Simple, Sensitive, Fluorometric Screening Test for Lead Poisioning. Clin. Chem. 1975, 21, 93-97. [CrossRef] [PubMed]

260. A Lamola, A.; Eisinger, J.; E Blumberg, W.; Kometani, T.; Burnham, B.F. Quantitative determination of erythrocyte zinc protoporphyrin. J. Lab. Clin. Med. 1977, 89, 881-890. [PubMed]

261. Hanna, T.L.; Dietzler, D.N.; Smith, C.H.; Gupta, S.; Zarkowsky, H.S. Erythrocyte porphyrin analysis in the detection of lead poisoning in children: Evaluation of four micromethods. Clin. Chem. 1976, 22, 161-168. [CrossRef]

262. Hart, D.; Piomelli, S. Simultaneous quantitation of zinc protoporphyrin and free protoporphyrin in erythrocytes by acetone extraction. Clin. Chem. 1981, 27, 220-222. [CrossRef] [PubMed]

263. E Blumberg, W.; Eisinger, J.; A Lamola, A.; Zuckerman, D.M. The hematofluorometer. Clin. Chem. 1977, 23, 270-274. [CrossRef]

264. Niinuma, Y.; Sakai, T.; Yanagihara, S.; Ushio, K. Relationship between ZP levels by hematofluorometer and the other biological parameters of lead exposure. Jpn. J. Traumatol. Occup. Med. 1982, 30, 816-824. 
265. Sakai, T.; Takeuchi, Y.; Ikeya, Y.; Araki, T.; Ushio, K. Automated HPLC method for determining zinc protoporphyrin ix and protoporphyrin ix in erythrocytes of workers exposed to lead. Sangyo Igaku 1988, 30, 467-474. [CrossRef]

266. Sakai, T.; Takeuchi, Y.; Araki, T.; Ushio, K. Determination of erythrocyte porphyrins by reversed-phase high-performance liquid chromatography using capsule-type silica gels coated with silicone polymer. J. Chromatogr. B Biomed. Sci. Appl. 1988, 433, 73-79. [CrossRef]

267. A Lemos, V.; Ferreira, S.L. On-line preconcentration system for lead determination in seafood samples by flame atomic absorption spectrometry using polyurethane foam loaded with 2-(2-benzothiazolylazo)-2-p-cresol. Anal. Chim. Acta 2001, 441, 281-289. [CrossRef]

268. Okayama, A.; Fujii, S.; Miura, R. Optimized fluorometric determination of urinary delta-aminolevulinic acid by using pre-column derivatization, and identification of the derivative. Clin. Chem. 1990, 36, 1494-1497. [CrossRef]

269. Valentine, W.N.; Fink, K.; Paglia, D.E.; Harris, S.R.; Adams, W.S. Hereditary hemolytic anemia with human erythrocyte pyrimidine 5'-nucleotidase deficiency. J. Clin. Invest. 1974, 54, 866-879. [CrossRef] [PubMed]

270. Baloh, R.W. Laboratory Diagnosis of Increased Lead Absorption. Arch. Environ. Heal. Int. J. 1974, 28, $198-208$. [CrossRef] [PubMed]

271. Sakai, T.; Yanagihara, S.; Ushio, K. Determination of 5'-nucleotidase activity in human erythrocytes and plasma using high-performance liquid chromatography. J. Chromatogr. A 1982, 239, 717-721. [CrossRef]

272. Sakai, T.; Ushio, K. A simplified method for determining erythrocyte pyrimidine 5 '-nucleotidase (P5N) activity by HPLC and its value in monitoring lead exposure. Occup. Environ. Med. 1986, 43, 839-844. [CrossRef]

273. Zerez, C.R.; Tanaka, K.R. Impaired nicotinamide adenine dinucleotide synthesis in pyruvate kinase-deficient human erythrocytes: A mechanism for decreased total NAD content and a possible secondary cause of hemolysis. Blood 1987, 69, 999-1005. [CrossRef]

274. Sakai, T.; Morita, Y.; Araki, T.; Masuyama, Y. Simple and rapid method for determining nicotinamide adenine dinucleotide synthetase activity by high-performance liquid chromatography. J. Chromatogr. B Biomed. Sci. Appl. 1997, 704, 77-81. [CrossRef]

275. Khaled, A.; El Nemr, A.; El Sikaily, A. Contamination of coral reef by heavy metals along the Egyptian Red Sea coast. Bull. Environ. Contam. Toxicol. 2003, 71, 577-584. [CrossRef]

276. Khaled, A.; El Nemr, A.; El Sikaily, A. An assessment of heavy-metal contamination in surface sediments of the Suez Gulf using geoaccumulation indexes and statistical analysis. Chem. Ecol. 2006, 22, 239-252. [CrossRef]

277. El-Sikaily, A.; Khaled, A.; El Nemr, A. Heavy metals monitoring using bivalves from Mediterranean Sea and Red Sea. Environ. Monit. Assess. 2004, 98, 41-58. [CrossRef]

278. El Sikaily, A.; Khaled, A.; El Nemr, A. Leachable and total heavy metals in muddy and sandy sediments collected from Suez Gulf. Egypt. J. Aquat. Res. 2005, 31, 99-119.

279. El Nemr, A.; Khaled, A.; El Sikaily, A. Distribution and Statistical Analysis of Leachable and Total Heavy Metals in the Sediments of the Suez Gulf. Environ. Monit. Assess. 2006, 118, 89-112. [CrossRef] [PubMed]

280. Youssef, D.H.; El-Said, G.F. Assessment of some heavy metals in surface sediments of the Aqaba Gulf, Egypt. Environ. Monit. Assess. 2011, 180, 229-242. [CrossRef] [PubMed]

281. Gabr, H.R.; Gab-Alla, A.F. Effect of transplantation on heavy metal concentrations in commercial clams of Lake Timsah, Suez Canal, Egypt. Oceanologia 2008, 50, 83-93.

282. Idris, A.M.; Eltayeb, M.; Potgieter-Vermaak, S.; Van Grieken, R.; Potgieter, J. Assessment of heavy metals pollution in Sudanese harbours along the Red Sea Coast. Microchem. J. 2007, 87, 104-112. [CrossRef]

283. Awaleh, M.O.; Bouraleh, H.F.; Soubaneh, Y.D.; Badran, M.; Bahga, H.O.; Samaleh, A.I. Impact of Human Activity on Marine and Coastal Environment in the Gulf of Tadjourah. J. Mar. Sci. Res. Dev. 2015, 5. [CrossRef]

284. Mwashote, B.M. Levels of Cadmium and Lead in Water, Sediments and Selected Fish Species in Mombasa, Kenya. West. Indian Ocean J. Mar. Sci. 2004, 2, 25-34. [CrossRef]

285. Maritim, P.K.; Gachanja, A.; Munyao, T.M. Speciation of Trace Metals Pb, Zn, Cu and Cd in Surficial Sediment from Makupa Creek Mombasa, Coastal Kenya. OALib 2016, 3, 1-10. [CrossRef]

286. Mshana, J.G.; Sekadende, B. Assessment of Heavy Metal Pollution in Octopus cyanea in the Coastal Waters of Tanzania. J. Heal. Pollut. 2014, 4, 10-17. [CrossRef] 
287. Fatoki, O.S.; Okoro, H.; Adekola, F.; Ximba, B.; Snyman, R.G. Bioaccumulation of metals in black mussels (Mytilus galloprovincialis) in Cape Town Harbour, South Africa. Environmentalist 2011, 32, 48-57. [CrossRef]

288. Boldrocchi, G.; Monticelli, D.; Omar, Y.M.; Bettinetti, R. Trace elements and POPs in two commercial shark species from Djibouti: Implications for human exposure. Sci. Total. Environ. 2019, 669, 637-648. [CrossRef]

289. El Nemr, A.; El-Said, G.F.; Ragab, S.; Khaled, A.; El-Sikaily, A. The distribution, contamination and risk assessment of heavy metals in sediment and shellfish from the Red Sea coast, Egypt. Chemosphere 2016, 165, 369-380. [CrossRef] [PubMed]

290. El-Moselhy, K.M.; Othman, A.; El-Azem, H.A.; El-Metwally, M. Bioaccumulation of heavy metals in some tissues of fish in the Red Sea, Egypt. Egypt. J. Basic Appl. Sci. 2014, 1, 97-105. [CrossRef]

291. Shilla, D.A. Distribution of $\mathrm{Pb}, \mathrm{Cr}, \mathrm{Cu}$ and $\mathrm{Zn}$ in the marine-coastal region of Zanzibar (Tanzanian archipelago, East Africa). Chem. Ecol. 2016, 32, 1-12. [CrossRef]

292. Kojadinovic, J.; Potier, M.; Le Corre, M.; Cosson, R.P.; Bustamante, P. Bioaccumulation of trace elements in pelagic fish from the Western Indian Ocean. Environ. Pollut. 2007, 146, 548-566. [CrossRef] [PubMed]

293. Gomaa, M.; Abou-Arab, A.A.K.; Badawy, A.; Khayria, N. Distribution pattern of some heavy metals in Egyptian fish organs. Food Chem. 1995, 53, 385-389. [CrossRef]

294. Salam, H.A. Heavy Metals Monitoring Using Commercially Important Crustacean and Mollusks collected from Egyptian and Saudi Arabia Coasts. Anim. Veter- Sci. 2014, 2, 49. [CrossRef]

295. Mziray, P.; Kimirei, I.A. Bioaccumulation of heavy metals in marine fishes (Siganus sutor, Lethrinus harak, and Rastrelliger kanagurta) from Dar es Salaam Tanzania. Reg. Stud. Mar. Sci. 2016, 7, 72-80. [CrossRef]

296. Authman, M.M. Use of Fish as Bio-indicator of the Effects of Heavy Metals Pollution. J. Aquac. Res. Dev. 2015, 6, 1-13. [CrossRef]

297. Authman, M.M.; Abbas, W.; Gaafar, A.Y. Metals concentrations in Nile tilapia Oreochromis niloticus () from illegal fish farm in Al-Minufiya Province, Egypt, and their effects on some tissues structures. Ecotoxicol. Environ. Saf. 2012, 84, 163-172. [CrossRef]

298. Whitfield, A.; Elliott, M. Fishes as indicators of environmental and ecological changes within estuaries: A review of progress and some suggestions for the future. J. Fish Biol. 2002, 61, 229-250. [CrossRef]

299. Khallaf, E.A.; Galal, M.; Authman, M. Assessment of heavy metals pollution and their effects on Oreochromis niloticus in aquatic drainage canals. J. Egypt. Ger. Soc. Zool. 1998, 26, 39-74.

300. Al-Yousuf, M.; El-Shahawi, M.; Al-Ghais, S. Trace metals in liver, skin and muscle of Lethrinus lentjan fish species in relation to body length and sex. Sci. Total. Environ. 2000, 256, 87-94. [CrossRef]

301. Çavaş, T.; Garanko, N.N.; Arkhipchuk, V.V. Induction of micronuclei and binuclei in blood, gill and liver cells of fishes subchronically exposed to cadmium chloride and copper sulphate. Food Chem. Toxicol. 2005, 43, 569-574. [CrossRef] [PubMed]

302. Van Dyk, J.; Pieterse, G.; Van Vuren, J.; Van Vuren, J. Histological changes in the liver of Oreochromis mossambicus (Cichlidae) after exposure to cadmium and zinc. Ecotoxicol. Environ. Saf. 2007, 66, 432-440. [CrossRef]

303. Giari, L.; Manera, M.; Simoni, E.; Dezfuli, B.S. Cellular alterations in different organs of European sea bass Dicentrarchus labrax (L.) exposed to cadmium. Chemosphere 2007, 67, 1171-1181. [CrossRef]

304. Omer, S.A.; Elobeid, M.A.; Fouad, D.; Daghestani, M.; Al-Olayan, E.M.; Elamin, M.H.; Virk, P.; El-Mahassn, A. Cadmium Bioaccumulation and Toxicity in Tilapia Fish (Oreochromis niloticus). J. Anim. Veter- Adv. 2012, 11, 1601-1606. [CrossRef]

305. Vetillard, A.; Bailhache, T. Cadmium: An Endocrine Disrupter That Affects Gene Expression in the Liver and Brain of Juvenile Rainbow Trout1. Boil. Reprod. 2005, 72, 119-126. [CrossRef]

306. Mukherjee, D.; Kumar, V.; Chakraborti, P. Effect of mercuric chloride and cadmium chloride on gonadal function and its regulation in sexually mature common carp Cyprinus carpio. Biomed. Environ. Sci. 1994, 7, $13-24$.

307. Vijayram, K.; Geraldine, P.; Varadarajan, T.S.; John, G.; Loganathan, P. Cadmium induced changes in the biochemistry of an air breathing fish Anabas testudineus. J. Ecobiol. 1989, 4, 245-251.

308. Sanchez-Galan, S.; Linde, A.; Ayllon, F.; Vazquez, E.G. Induction of Micronuclei in Eel (Anguilla anguilla L.) by Heavy Metals. Ecotoxicol. Environ. Saf. 2001, 49, 139-143. [CrossRef]

309. Jia, X.; Zhang, H.; Liu, X. Low levels of cadmium exposure induce DNA damage and oxidative stress in the liver of Oujiang colored common carp Cyprinus carpio var. color. Fish Physiol. Biochem. 2010, 37, 97-103. [CrossRef] [PubMed] 
310. Souid, G.; Souayed, N.; Yaktiti, F.; Maaroufi, K. Effect of acute cadmium exposure on metal accumulation and oxidative stress biomarkers of Sparus aurata. Ecotoxicol. Environ. Saf. 2013, 89, 1-7. [CrossRef] [PubMed]

311. Witeska, M.; Sarnowski, P.; Ługowska, K.; Kowal, E. The effects of cadmium and copper on embryonic and larval development of ide Leuciscus idus L. Fish Physiol. Biochem. 2013, 40, 151-163. [CrossRef] [PubMed]

312. Low, J.; Higgs, D.M. Sublethal effects of cadmium on auditory structure and function in fathead minnows (Pimephales promelas). Fish Physiol. Biochem. 2014, 41, 357-369. [CrossRef] [PubMed]

313. Katti, S.; Sathyanesan, A. Lead nitrate induced changes in lipid and cholesterol levels in the freshwater fish Clarias batrachus. Toxicol. Lett. 1983, 19, 93-96. [CrossRef]

314. Olojo, E.A.A.; Olurin, K.B.; Mbaka, G.; Oluwemimo, A.D. Histopathology of the gill and liver tissues of the African catfish Clarias gariepinus exposed to lead. Afr. J. Biotechnol. 2005, 4, 117-122.

315. Hou, J.L.; Zhuang, P.; Zhang, L.Z.; Feng, L.; Zhang, T.; Liu, J.Y.; Feng, G.P. Morphological deformities and recovery, accumulation and elimination of lead in body tissues of Chinese sturgeon, Acipenser sinensis, early life stages: A laboratory study. J. Appl. Ichthyol. 2011, 27, 514-519. [CrossRef]

316. Kirubagaran, R.; Joy, K. Toxic effects of three mercurial compounds on survival, and histology of the kidney of the catfish Clarias batrachus (L.). Ecotoxicol. Environ. Saf. 1988, 15, 171-179. [CrossRef]

317. Mona, S.Z.; Nabila, E.; Fawzi, O.M.; Awad, I.; Nagwa, S.A. Effect of mercuric oxide toxicity on some biochemical parameters on African cat fish Clarias gariepinus present in the River Nile. Life Sci. J. 2011, 8, 363-368.

(C) 2020 by the authors. Licensee MDPI, Basel, Switzerland. This article is an open access article distributed under the terms and conditions of the Creative Commons Attribution (CC BY) license (http://creativecommons.org/licenses/by/4.0/). 